\title{
21. FLUID INCLUSION PETROGRAPHY AND MICROTHERMOMETRY OF THE MIDDLE VALLEY HYDROTHERMAL SYSTEM, NORTHERN JUAN DE FUCA RIDGE ${ }^{1}$
}

\author{
Jan M. Peter, ${ }^{2}$ Wayne D. Goodfellow, ${ }^{2}$ and Matthew I. Leybourne ${ }^{2}$
}

\begin{abstract}
Middle Valley is a hydrothermally active, sediment-covered rift at the northernmost end of the Juan de Fuca Ridge. Two hydrothermal centers are known from previous work: (1) a 60-m-high sediment mound with a 35-m-high inactive sulfide mound and two 20-m-high sulfide mounds $330 \mathrm{~m}$ to the south, one of which is known to be active, and (2) several mounds with attendant active hydrothermal chimneys. These sites (Sites 856 and 858, respectively), as well as other adjacent areas (Sites 857 and 855 ), were drilled during Leg 139 of the Ocean Drilling Program. Fluid inclusion petrographic observations and microthermometric measurements were made on a variety of samples and minerals recovered from these cores: (1) quartz from hydrothermally altered sediment; (2) low iron sphalerite and interstitial dolomite in massive sulfide; (3) calcite-sulfide veins cross-cutting sediment; (4) calcite and anhydrite concretions in sediment; (5) anhydrite veins cross-cutting sediment; and (6) wairakite and quartz veins cross-cutting mafic sills and sediment. Trapping temperatures of fluid inclusions in hydrothermal alteration minerals precipitated with massive sulfides range between $90^{\circ}$ and $338^{\circ} \mathrm{C}$. Fluid inclusions in calcite in carbonate concretions indicate these concretions formed between $112^{\circ}$ and $192^{\circ} \mathrm{C}$. Anhydrite in veins and concretions was precipitated between $137^{\circ}$ and $311^{\circ} \mathrm{C}$. Quartz-wairakiteepidote veins in mafic sills and hydrothermally altered sediment were precipitated between $210^{\circ}$ and $350^{\circ} \mathrm{C}$. For all inclusions, there is a general increase in minimum trapping temperatures with increasing subsurface depth for all sites, with temperatures ranging from around $100^{\circ} \mathrm{C}$ at 2400 meters below sea level to around $275^{\circ} \mathrm{C}$ at 3100 mbsl. Eutectic and hydrohalite melting temperatures indicate that $\mathrm{Ca}, \mathrm{Na}$, and $\mathrm{Cl}$ are the dominant ionic species present in the inclusion fluids. Salinities for most inclusion fluids range between 2.5 and 7.0 equivalent weight percent $\mathrm{NaCl}$. Most analyses are between 3 and 4.5 eq. wt $\% \mathrm{NaCl}$ and similar to ambient bottom water, pore fluids, and vent fluid from Site 858. Trapped fluids are modified seawater, and there is no evidence for a significant magmatic fluid component. Oxygen isotopic compositions for fluids from which calcite concretions were precipitated, calculated from isotopic analyses of carbonates formed at low temperatures $\left(133^{\circ}\right.$ to $158^{\circ} \mathrm{C}$ from fluid inclusions), are significantly enriched in ${ }^{18} \mathrm{O}\left(\delta^{18} \mathrm{O}=+9.3 \%\right.$ to $+13.2 \%$ ) , likely due to reaction with subsurface sediments at low water/rock ratios. Calcite that formed at higher temperatures $\left(233^{\circ} \mathrm{C}\right)$ in hydrothermally altered sediment was precipitated from fluid only slightly enriched in ${ }^{18} \mathrm{O}\left(\delta^{18} \mathrm{O}=+0.4 \%\right)$. Estimated carbon isotope compositions of the fluid vary between $\delta^{13} \mathrm{C}=-7.0 \% 0$ and $-35.4 \%$ and are similar to the measured range for vent fluids.
\end{abstract}

\section{INTRODUCTION}

Middle Valley (MV) is a sedimented rift on the east flank of Endeavor Segment of the Juan de Fuca Ridge, situated $300 \mathrm{~km}$ west of the continental margin of British Columbia and Washington (Fig. 1) (Davis et al., 1987). At least $350 \mathrm{~m}$ of turbiditic sediments overlie the basaltic basement (Davis, Mottl, Fisher, et al., 1992). Drill cores were recovered during Leg 139 of the Ocean Drilling Program (ODP) from the two areas of known hydrothermal venting and sulfide precipitation: (1) active hydrothermal vents termed the area of active venting (AAV), and (2) an older, hydrothermally inactive massive sulfide mound, referred to as Bent Hill (BH). At these sites, hydrothermal precipitates form mounds and chimneys at around $2450 \mathrm{~m}$ water depth.

Here we present fluid inclusion petrography and microthermometry results obtained from samples recovered from the MV hydrothermal system during Leg 139. Previous physical and chemical measurements of actively venting hydrothermal fluids (Butterfield et al., this volume; Franklin and Leg 139 Scientific Party, 1992; Lydon et al., 1992) and downhole temperature profiles obtained during Leg 139 provide information on current hydrothermal conditions. Fluid inclusions, however, allow the determination of paleo-hydrothermal conditions. Samples studied include: (1) quartz from indurated sediments that are interpreted to represent a high-temperature quartz-muscovitechlorite upflow zone (BH); (2) quartz-wairakite-epidote veins from the hydrothermal reaction zone (Site 857) and upflow zone (AAV); (3) carbonate and anhydrite from the outer lower temperature margin

\footnotetext{
'Mottl, M.J., Davis, E.E., Fisher, A.T., and Slack, J.F. (Eds.), 1994. Proc. ODP, Sci. Results, 139: College Station, TX (Ocean Drilling Program).

${ }^{2}$ Mineral Resources Division, Geological Survey of Canada, 601 Booth Street, Ottawa, Ontario K1A 0E8, Canada.
}

of the upflow zone at AAV; and (4) carbonate and sphalerite from massive sulfide at $\mathrm{BH}$.

Previous work on two-phase, aqueous inclusions in anhydrite from active chimneys at AAV reported temperatures of $265^{\circ} \mathrm{C}$, comparable to measured vent temperatures up to $276^{\circ} \mathrm{C}$, and salinities between 2.2 and 4.0 equivalent weight percent $\mathrm{NaCl}$ (calculated from the freezing data of Leitch, 1991). Barite from a hydrocarbon-bearing, clay-rich, inactive chimney contains primary aqueous inclusions with homogenization temperatures of $170^{\circ} \mathrm{C}$ and hydrocarbon-bearing inclusions with homogenization temperatures of $110^{\circ} \mathrm{C}$ (Leitch, 1991). Simoneit et al. (1992) have estimated that hydrothermal petroleum within chimneys was formed at temperatures below about $120^{\circ} \mathrm{C}$ from 29 -ka carbon. No hydrocarbon-bearing inclusions were observed in the present study.

\section{GEOLOGICAL SETTING}

\section{Site 856 (Bent Hill)}

BH is a 500 -m-diameter by 60 -m-high, subcircular uplifted block of sediment in the eastern part of MV (Fig. 1) (Davis and Sawyer, 1987; Goodfellow and Blaise, 1988; Franklin et al., 1991; Goodfellow and Franklin, in press). Sulfides are exposed in a 35-m-high by $200-\mathrm{m}-$ wide sulfide mound about $100 \mathrm{~m}$ south of $\mathrm{BH}$ (Fig. 2). A single mound $330 \mathrm{~m}$ south of $\mathrm{BH}$ with $264^{\circ} \mathrm{C}$ vent was discovered during dives with the submersible ALVIN (Franklin et al., 1991) (Fig. 2). Drilling during Leg 139 recovered $96 \mathrm{~m}$ of massive sulfide from Hole $856 \mathrm{H}$ and $65 \mathrm{~m}$ from Hole $856 \mathrm{G}$. In this study, samples from four holes drilled at Site 856 were investigated. Hole $856 \mathrm{~B}$, on the southern margin of $\mathrm{BH}$ (Fig. 2), intersected slumped massive sulfide and variably altered hemipelagic and turbiditic sediment. The bottom of this hole (Core 139$856 \mathrm{~B}-15 \mathrm{X}$ ) consists of indurated siltstone to sandstone that has been altered to an assemblage of quartz-Fe-rich chlorite-muscovite-rutile 


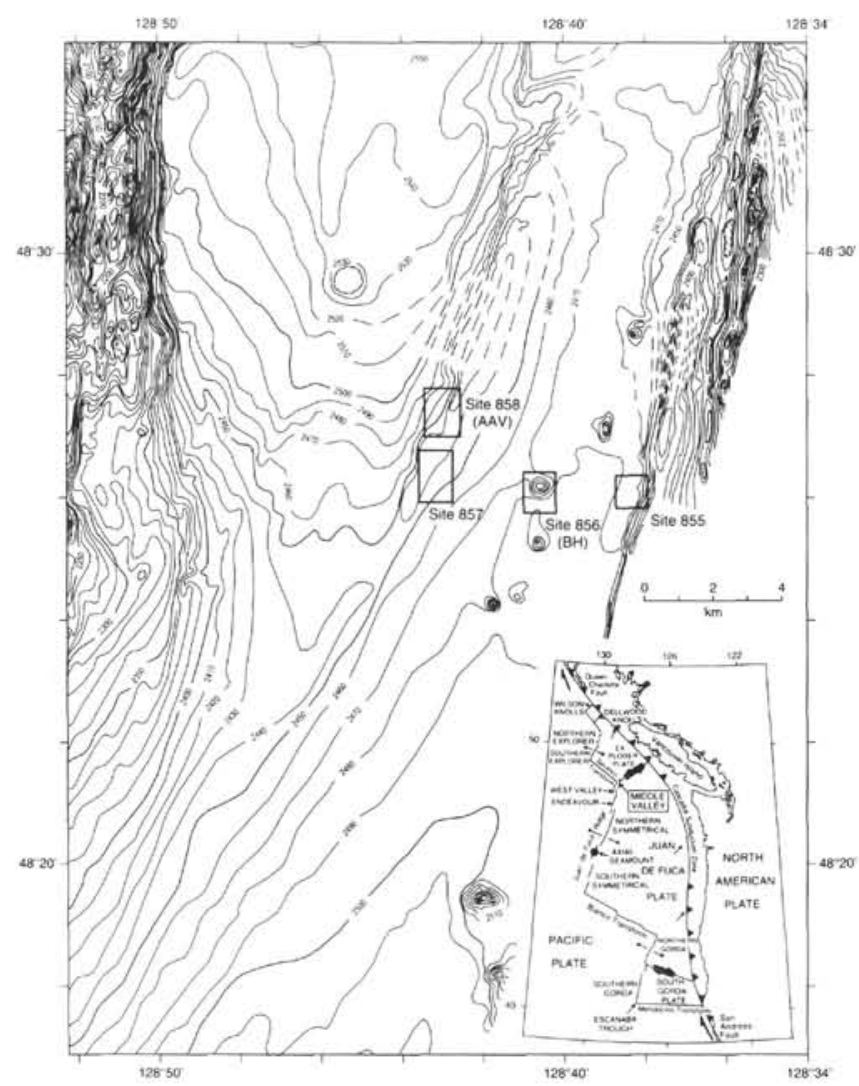

Figure 1. Location map of Middle Valley hydrothermal sites $(\mathrm{AAV}=$ area of active venting; $\mathrm{BH}=\mathrm{Bent}$ Hill). Inset shows location of Middle Valley on the Juan de Fuca Ridge System.

\pm chalcopyrite \pm pyrite \pm pyrrhotite. Hydrothermal alteration consists of up to $2 \mathrm{~mm}$ aggregates of chalcopyrite, pyrite, and quartz which entirely replace detrital minerals (Table 1; Goodfellow and Peter, this volume). Hole $856 \mathrm{~F}$, just south of $\mathrm{BH}$ (Fig. 2), contains sulfide (pyrite, pyrrhotite, chalcopyrite, and sphalerite) clasts within a finer grained sediment matrix. Cores from Holes $856 \mathrm{G}$ and $856 \mathrm{H}$ (Fig. 2) from the most northerly sulfide mound consist predominantly of massive sulfide (pyrite-pyrrhotite-sphalerite-chalcopyrite-magnetite) with interstitial Mg-silicates (talc, serpentine, $\mathrm{Mg}$-rich chlorite) and carbonate, and cross-cutting carbonate and silicate veins. This carbonate is principally dolomite, with lesser calcite, magnesite, and siderite (Leybourne and Goodfellow, this volume). Two generations of sphalerite occur in Hole 856G: early, opaque, high-iron and later, translucent, low-iron sphalerite. Due to the opacity of the former variety, only inclusions in low-iron sphalerite could be studied. In summary, Site 856 represents a fossil, inactive, high-temperature upflow zone.

\section{Site 857}

Site 857 (Fig. 1) is located $5.2 \mathrm{~km}$ west of the normal fault scarp that forms the eastern topographic boundary of $\mathrm{MV}$, and is about 1.5 $\mathrm{km}$ east of the sediment-buried fault that forms the current structural boundary of the central part of the rift. Sediments here consist of late Pleistocene to Holocene interbedded hemipelagic mud and turbiditic silt and sand that have been intruded by mafic sills below 465 meters below seafloor (mbsf). Site 857 is an area of high heat flow, typically over $0.8 \mathrm{~W} \mathrm{~m}^{-2}$ (Davis, Goodfellow, et al., 1987), and is $1.6 \mathrm{~km}$ south of AAV (Site 858), where fluids actively vent at temperatures up to $276^{\circ} \mathrm{C}$ (Franklin et al., 1991). The three holes drilled at this site continuously sample the stratigraphic sequence to $936 \mathrm{mbsf}$. Samples from Holes 857C and 857D were used in this study. The lower portions of

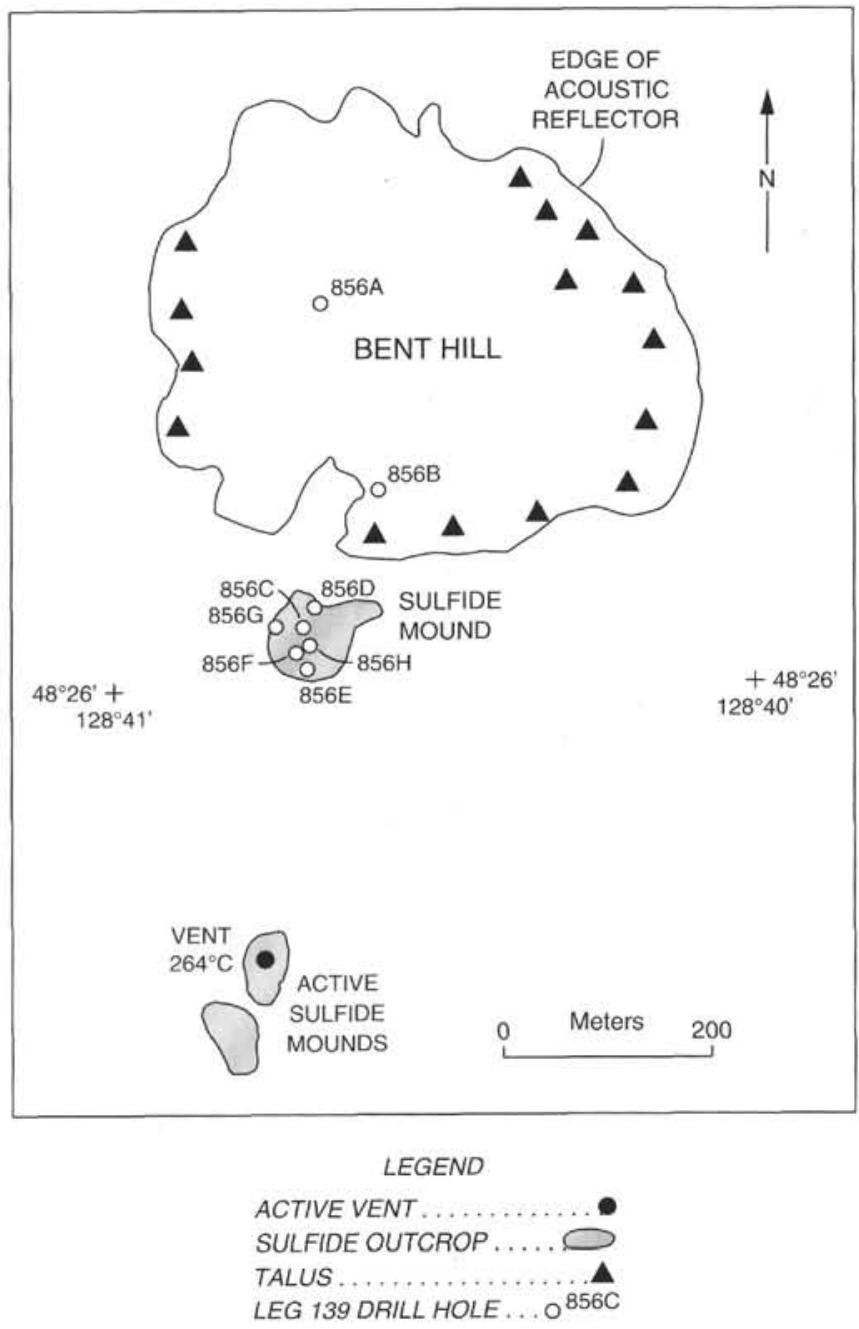

Figure 2. Map showing the $\mathrm{BH}$ sediment mound mapped by the limit of the acoustically reflective area, the inactive $\mathrm{BH}$ sulfide deposit near the southern flank of the sediment mound, and two sulfide mounds about $330 \mathrm{~m}$ south of $\mathrm{BH}$, one of which is actively venting high-temperature fluids from an anhydrite-sulfide chimney. Also shown are locations of ODP drill holes, sulfide outcrop, and talus.

Holes $857 \mathrm{C}$ and $857 \mathrm{D}$ are composed of indurated, hydrothermally altered siltstone to claystone, with cross-cutting hydrothermal veins of quartz, wairakite, epidote, and pyrite. Mafic sills are common here (Stakes and Franklin, this volume) and host two styles of crosscutting veins: (1) iron sulfide-chlorite \pm epidote veins, and (2) quartzwairakite-epidote \pm actinolite veins (Davis, Mottl, Fisher, et al., 1992). In summary, Site 857 is a reaction zone for fluids that are presently venting at Site 858 (Goodfellow and Peter, this volume).

\section{Site 858 (Area of Active Venting)}

This site hosts a flat, north-trending, $700-\mathrm{m}$ by 400 -m hydrothermally active area referred to as AAV (Goodfellow and Blaise, 1988) (Fig. 1). Dives with the submersible ALVIN during the summer of 1990 recorded temperatures of hydrothermal fluid venting up to $276^{\circ} \mathrm{C}$ from chimneys on mounds typically measuring $25 \mathrm{~m}$ in diameter and $7 \mathrm{~m}$ in height (Franklin et al., 1991). Hole 858A, drilled $100 \mathrm{~m}$ west of AAV and Hole $858 \mathrm{C}, 70 \mathrm{~m}$ west of the vent field (Fig. 3), cored moderately altered hemipelagic and turbiditic sediments that host $1-$ to $8-\mathrm{cm}$ diameter carbonate concretions, and anhydrite nodules and veins. Carbonate also infills and replaces worm burrows at AAV (Goodfellow et 
al., 1994). Hole $858 \mathrm{~B}$ was drilled a few meters from a $276^{\circ} \mathrm{C}$ vent, and $\mathrm{Mg}$-rich sediments and massive sulfide with interstitial carbonate were recovered. Hole $858 \mathrm{~F}$ was drilled near the center of the vent field (Fig. 3). Cores are altered and indurated sandstone to claystone with rare matrix wairakite, and have been cut by quartz-wairakite-epidote veins. In summary, Site 858 is a presently active, low-temperature hydrothermal system which is not precipitating significant sulfide mineralization; hydrothermal mineralization is predominantly anhydrite chimneys on sediment mounds (Goodfellow and Franklin, in press).

\section{ANALYTICAL METHODS}

Fluid inclusion microthermometric measurements were made on crystals that were hand-picked from friable and readily disaggregated samples, and on doubly polished thin sections made from indurated and/or fine-grained samples, prepared by the method of Holland et al. (1978). Homogenization temperatures and freezing point depressions were determined with a Linkam TH600 fluid inclusion stage (Shepherd, 1981) calibrated according to the method of MacDonald and Spooner (1981). Calibrations were made using pure substances and Merck® chemical standards of known melting temperatures. The accuracy of a temperature measurement is estimated to be within $\pm 7^{\circ} \mathrm{C}$ at around $400^{\circ} \mathrm{C}$ and $\pm 0.2^{\circ} \mathrm{C}$ at and below $0^{\circ} \mathrm{C}$, and the reproducibility is estimated at $\pm 2^{\circ} \mathrm{C}$ around $300^{\circ}$ to $400^{\circ} \mathrm{C}$ and $\pm 0.2^{\circ} \mathrm{C}$ at and below $0^{\circ} \mathrm{C}$. For freezing measurements, fluid inclusions were supercooled to $-100^{\circ} \mathrm{C}$ or cooler until completely frozen and were then slowly heated.

Four samples of calcite and two samples of dolomite for which fluid inclusion trapping temperatures $\left(T_{t}\right)$ were determined were selected for stable carbon and oxygen isotope analysis. Samples were powdered and $\mathrm{CO}_{2}$ was extracted with $100 \% \mathrm{H}_{3} \mathrm{PO}_{4}$ according to the method of McCrea (1950) as follows: samples were reacted for $2 \mathrm{hr}$ at $25^{\circ} \mathrm{C}$ to extract calcite $\mathrm{CO}_{2}$. After calcite was extracted, samples were reacted for an additional $12 \mathrm{hr}$, and this $\mathrm{CO}_{2}$ was disposed; the remaining sample was then reacted for 12 to $24 \mathrm{hr}$ at $50^{\circ} \mathrm{C}$ to extract dolomite $\mathrm{CO}_{2}$. Carbonate minerals were mechanically separated at the Geological Survey of Canada and chemically purified and analyzed at the Ottawa-Carleton Geoscience Centre (OCGC) Stable Isotope facility at the University of Ottawa. Isotope ratios were measured on a VG Micromass 602 mass spectrometer. The oxygen isotope data are reported relative to standard mean ocean water (SMOW), and the carbon isotope compositions to the Peedee belemnite (PDB) reference standard. Precision for both the $\delta^{18} \mathrm{O}$ and $\delta^{13} \mathrm{C}$ analyses is $\pm 0.1 \%(2 \sigma)$.

\section{RESULTS}

\section{Mineralogy and Fluid Inclusion Petrography}

Fluid inclusions were measured in quartz, calcite, dolomite, and anhydrite, which are present as alteration minerals in the groundmass of hydrothermally altered sediment; in sphalerite and dolomite in massive sulfide; in calcite in carbonate concretions; and in quartz, wairakite, and anhydrite in veins. Summary descriptions of the samples studied, their mineralogy, and fluid inclusion petrography are given in Table 1. Additionally, Leybourne and Goodfellow (this volume) give a more detailed description of the style and mode of alteration minerals within which we measured fluid inclusions. Plate 1 is a composite of transmitted light photomicrographs of fluid inclusion sections of representative samples. Samples include sulfide with interstitial carbonate without cross-cutting veinlets (PI. 1A) and with cross-cutting veinlets (Pl. 1B), hydrothermally altered (quartz and sulfides), fine-grained laminated sediment without cross-cutting veinlets (PI. 1C) and with cross-cutting veinlets (Pl. 1D), mafic sill with cross-cutting quartzwairakite-epidote veinlets (Pl. 1E), and coarse-grained carbonate concretions (Pl. 1F). Authigenic quartz from hydrothermally altered sediment may be anhedral to euhedral and replaces detrital quartz, feldspar, and other constituents (Leybourne and Goodfellow, this volume). Calcite and dolomite within hydrothermally altered sediment is generally

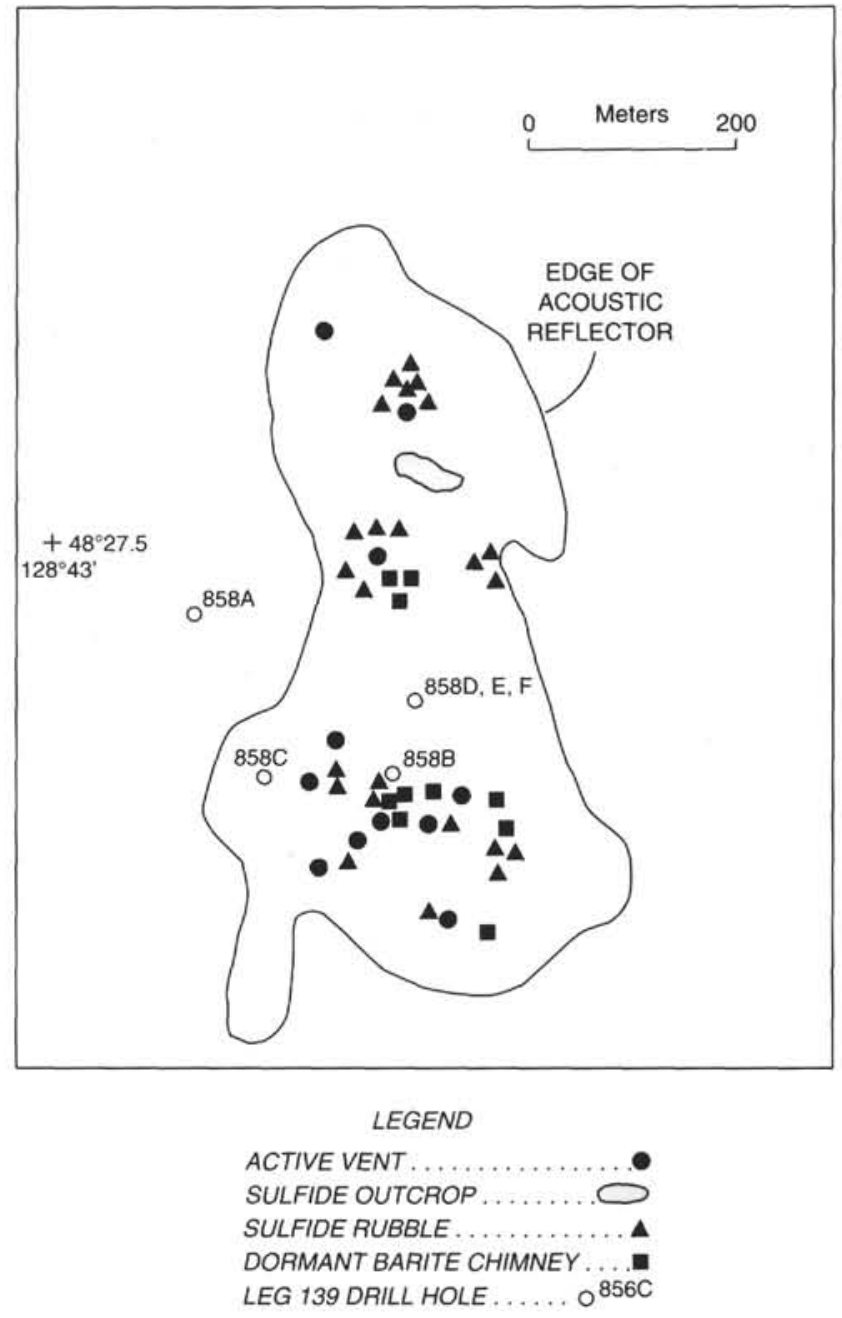

Figure 3. Map of the AAV showing the limit of the acoustically reflective area and locations of ODP drill holes, active vents, sulfide outcrop, sulfide rubble, and barite chimneys.

anhedral, whereas that from cross-cutting veinlets generally is subhedral to anhedral.

Fluid inclusions have been classified according to the criteria of Roedder (1984) to discriminate between primary and secondary inclusions, and descriptions of these inclusion types are given below. Both primary inclusions, which are interpreted to contain the extant hydrothermal fluid during mineral growth, and secondary inclusions, which are interpreted to have trapped fluids after mineral precipitation, such as along healed fractures (Roedder, 1984), are present in all sample types. As pointed out by Peter and Scott (1988) and Vanko (1988), however, given the rapid precipitation of hydrothermal minerals in such seafloor settings, fluids in primary inclusions may actually be introduced along fractures in the host minerals and be preserved in secondary-appearing inclusions. Thus, inclusions classified as secondary here may actually be pseudosecondary inclusions according to the criteria of Roedder (1984).

\section{Primary Inclusions}

Primary inclusions occur as either isolated inclusions, as small, three-dimensional clusters of inclusions located randomly within individual crystals, and as inclusions that occur with minute solid inclusions along growth zones in carbonate. Primary inclusions occur in 
Table 1. Description of Middle Valley fluid inclusion samples used in this study.

Sample Number Description Mineralogy

Fluid Inclusion Petrography \& Comments

$139-856 \mathrm{~B}-15 \mathrm{X}-2,67-69 \mathrm{~cm}$

Medium light grey, laminated, indurated, silty sandstone mineralized

Auth. Cly $(40 \%-50 \%)$, auth. $\mathrm{Qz}(40 \%)$,
auth. Ch $(5 \%), \mathrm{Ru}(<1 \%), \mathrm{Py}(1 \%), \mathrm{Cp}$ $(1 \%)$

$139-856 \mathrm{G}-7 \mathrm{R}-4,4-6 \mathrm{~cm}$

$139-856 \mathrm{H}-3 \mathrm{R}-2,16-18 \mathrm{~cm}$

$139-856 \mathrm{H}-3 \mathrm{R}-2,84-87 \mathrm{~cm}$

$139-857 \mathrm{C}-60 \mathrm{R}-2,28-30 \mathrm{~cm}$

$139-857 \mathrm{C}-61 \mathrm{R}-2,4-6 \mathrm{~cm}$

$139-857 \mathrm{C}-62 \mathrm{R}-1,67-69 \mathrm{~cm}$

$139-857 \mathrm{C}-64 \mathrm{R}-2,74-76 \mathrm{~cm}$

139-857D-1R-1, 137-139

139-857D-11R-1, 1-3 cm
Lithified sand with sulfide clasts within Carb matrix.

Dense to loose network of interlocking Py, with inclusions of $\mathrm{Cp}$ and early, high-Fe $\mathrm{Sp}$, and interstitial and rimming low-Fe Sp.

Heterogeneous medium to c.gr. Py and Mt, with interstitial Carb and Cly matrix.

Heterogeneous medium to c.gr. Py + Mt, with interstitial Do. Sample has a large subrounded clast of $\mathrm{Py}-\mathrm{Po}$.

Mafic sill with 0.2 to $1-\mathrm{mm}$-wide crosscutting Qz-Wa-
Ep vein.

Mafic sill with 2 to 10-mm-wide crosscutting Qz-Wa-Ep vein

Mafic sill with 20 to 30-mm-wide crosscutting Qz-Wa- Plag, Cpx, Ox, Ch, Sulf, Ep, Qz, Wa. Ep vein.

2 to 3-mm-wide Qz-Wa-Ep vein crosscutting mafic sill.

Plag, Cpx, Ox, Ch, Sulf., Ep, Qz, Wa.

Medium light gray indurated siltstone with a $0.2-\mathrm{mm}$ wide, crosscutting $Q z-E p$ vein.

Light gray, indurated sandstone with 5-mm-wide Qz, Fs, Ch, Ep, \& Wa + Qz vein fill. crosscutting vuggy $Q z-W_{a}-E p$ vein with euhedral $Q z$ crystals. $(<1 \%)$ $(3 \%), \mathrm{Ht}$ and $\mathrm{Gt}(<1 \%)$. $<1 \%$

Plag, Cpx, Ox, Ch, Sulf, Ep, Qz, Wa.
Carb (40\%), Py (25\%), Fe Ox (15-20\%),

$\operatorname{Py}(75-80 \%), \operatorname{Sp}(20 \%-25 \%), C p(<1 \%)$. Py $(40 \%)$, Do (18\%), auth. Cly \& Ch

Do(50\%), Py $(25 \%), P o(10 \%), S p$ Fluid inclusions measured in interstitial Do which occurs as anhedral to $10 \%-15 \%)$, Ep (1\%), Mi (1\%), Py (tr).

(s)

Plag, Cpx, Ox, Ch, Sulf, Ep, Qz, Wa

z(50\%-60\%), Cly/Ch (15\%-20\%), Fs Fluid inclusions measured in hand-picked vein $Q z$ which occurs as euhedral,
hexagonal, 1-3 mm long crystals with rare to common fluid inclusions. Few
isolated primary inclusions with rectangular morphologies and abundant
secondary inclusions with irregular to needle-like morphologies along healed fracture planes. 
Table 1 (continued).

139-85TD-12R-1, $88-90 \mathrm{~cm}$

Mafic sill with 0.3 to 1 -mm-wide crosscutting, antomosing vein.

139-858A-28X-CC, $4-5 \mathrm{~cm}$

139-858A-29X-1, 30-32 cm

139-858B-2H-3, $113-115 \mathrm{~cm}$

$139-858 \mathrm{~B}-2 \mathrm{H}-4,43-45 \mathrm{~cm}$

$139-858 \mathrm{C}-3 \mathrm{H}-1,78-81 \mathrm{~cm}$

$139-858 \mathrm{C}-3 \mathrm{H}-1,145-150 \mathrm{~cm}$

$139-858 \mathrm{C}-3 \mathrm{H}-2,10-15 \mathrm{~cm}$

$139-858 \mathrm{C}-3 \mathrm{H}-3,22-24 \mathrm{~cm}$

139-858F-2R-CC, 8-11 cm

139-858G-16R-1, 77-79 cm

inclusions with rounded, oval, and negative crystal morphologies.

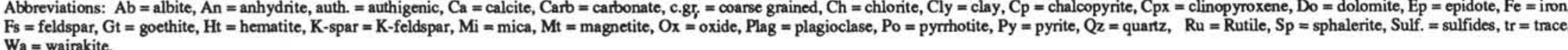
$\mathrm{Wa}=$ wairakite

Medium gray, indurated, thinly laninated siltstone with rounded clusters of nadiating Carb crystals and crosscutting 0.01 to 1.5 -mm-wide tension gash(?) veins filled with An

Light gray, indurated sandstone with crosscutting, 3-5 $\mathrm{mm}$ wide An vein.

Brecciated turbiditic sand with minor Cly; contains No thin section. An, Cly, Py. disseminated Py and large, auth. An crystals.

Olive gray-brown, non-indurated, silty $\mathrm{Cly}$ with No thin section. $\mathrm{Cly}, \mathrm{Py}, \mathrm{An}$. common disseminated Py and An.

Carb concretion with intricate network of crosscutting. 0.1 to $2 \mathrm{~mm}$ wide veinlets of Ca-Py.

$\mathrm{Ca}(90 \%), \operatorname{Py}(2 \%-3 \%), \mathrm{Cr}$ $(1 \%)$, Mi $(<1 \%)$, Plag (rare).

Ca concretion crosscut by 1 to 2 -mm-wide veins of No thin section. $\mathrm{Ca}, \mathrm{Cly}$. coarser-grained $\mathrm{Ca}$ in medium light olive-grey,

Ca concretion in light gray-olive, indurated silty Cly.

$\mathrm{Ca}(95 \%), \mathrm{Py}(3 \%), \mathrm{Qz}$ (1\%-2\%), Fs (tr), Pyrite is framboidal. Fluid inclusions measured in hand-picked, $0.025 \mathrm{~mm}$ $\mathrm{Ch}(\mathrm{tr}), \mathrm{Sp}$ (rare). anhedral Ca crystals. Abundant munded, rectangular, imegular to elongale primary and secondary inclusions distributed throughout crystals.

Light olive-grey, non-indurated clayey-silt with $\mathrm{Ca}$ No thin section. $\mathrm{Ca}, \mathrm{Oz}, \mathrm{Fs}$ crystals up to $4 \mathrm{~mm}$ in diameter and rare patches of Sulf.

Medium light gray, extremely indurated siltstone with a 3-mm-thick, crosscutting Oz-Wa vein. Adjacent to the vein is a 5 to 8 -mm-wide zone containing rounded bundles of Ch crystals.

Cly \& Ch $(85 \%-90 \%)$, Qz \& Fs $(5 \%$ $10 \%), \mathrm{Wa}(2 \%), \mathrm{Py}$ (rare), Mi (rare).

Fluid inclusions measured in hand picked, 1 to $4 \mathrm{~mm}$ diameter, euhedral $\mathrm{Ca}$ crystals. Moderately abundant,

teasured in hand picked, $0.2101 \mathrm{~mm}$ diameter, subhedral A crystals. Minor inclusions with irregular, elongate morphologies controlled by subhedral crystals.

Fuid inclusions measured in hand picked, 1 to 2 mm diameter vein Ca crystals. Fluid inclusions measured in hand picked, 1 to $2 \mathrm{~mm}$ diameter vein Ca crystals. chele abundant im

Fluid inclusions measured in vein $\mathrm{Wa}_{\mathrm{a}}$ which occurs as 1 to $2 \mathrm{~mm}$ diameter, sobedral crystals. Abundant rounded to oval primary inclusions distributed throughout crystals.

0.01 to $0.1 \mathrm{~mm}$, anhedr Mafic sill with 0.2 to 1.5-mm-wide crosscutting Qz-Wa- Plag, Cpx, Ox, Ch, Sulf, Ep, Qz, Wa. 

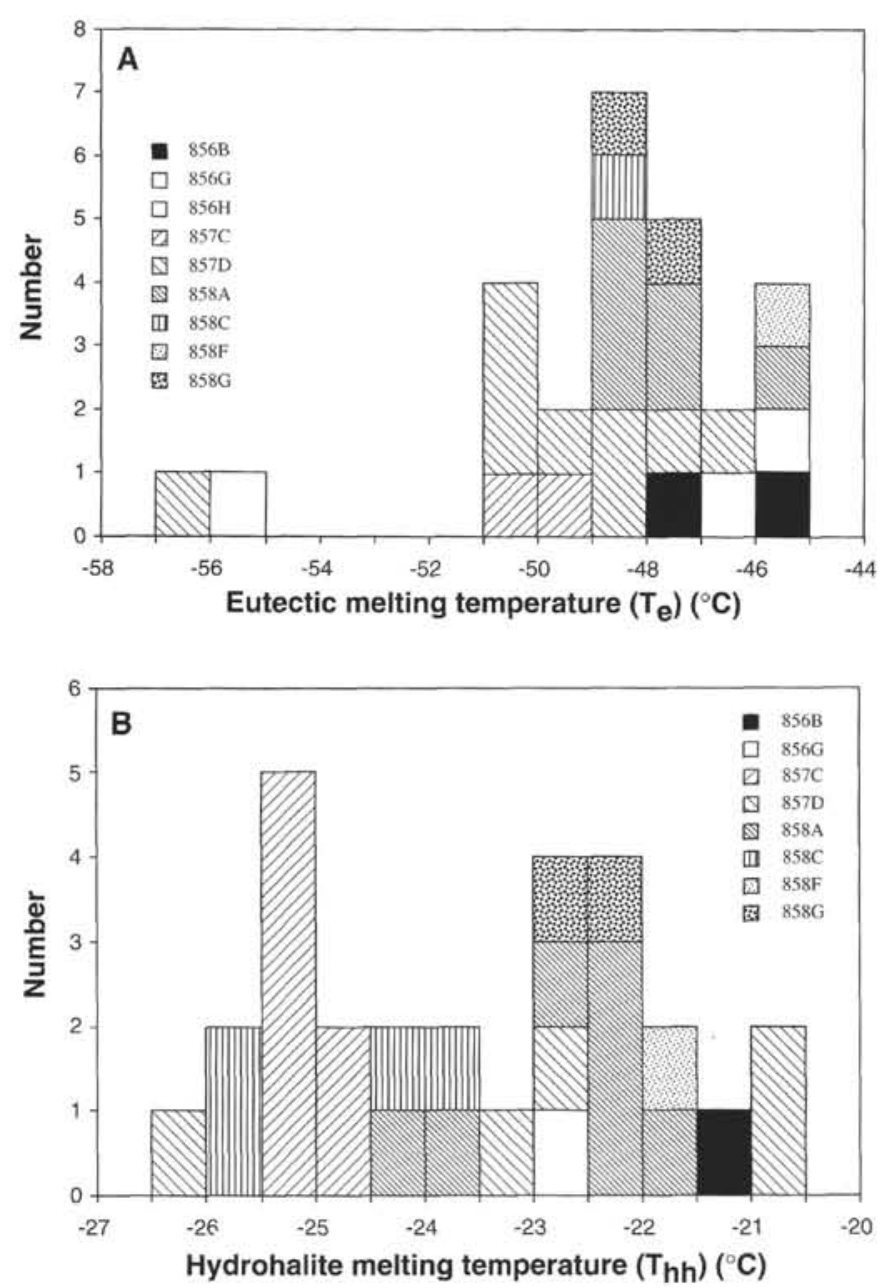

Figure 4. A. Frequency histogram of all observed eutectic melting temperatures for MV fluid inclusions. B. Frequency histogram of all observed hydrohalite melting temperatures for MV fluid inclusions.

quartz (Pl. 2A, -B, -C), sphalerite (Pl. 2D), anhydrite (Pl. 3A, -B), calcite and dolomite (Pl. 3C, -D), and wairakite (Pl. 3E). Primary inclusions in quartz range in diameter from $<3$ to about $15 \mu \mathrm{m}$, and are generally oval, circular, or hexagonal in cross section (Pl. 2A, -B, -C). Their size is generally uniform within a crystal. Primary inclusions in low-iron sphalerite range from $<4$ to $\approx 30 \mu \mathrm{m}$, and are oval, circular, or elongate (PI. 2D) in cross section or display negative crystal forms. Primary inclusions in anhydrite range from 2 to $70 \mu \mathrm{m}$ in diameter and are square, rectangular (Pl. 3A) and needle-like (Pl. 3B) in form. The orientation of these inclusions is controlled by the crystallographic axes of the anhydrite crystals. Primary inclusions in calcite vary in diameter between 2 and $180 \mu \mathrm{m}$ and in dolomite between 2 and $27 \mu \mathrm{m}$, and are oval, elongate, rectangular, and irregular in cross-section ( $\mathrm{Pl}, 3 \mathrm{C}$, -D). Inclusions in carbonate minerals are generally randomly distributed, although some samples display conspicuous growth zoning with individual zones marked by fluid inclusions and minute solid inclusions ( $\mathrm{Pl} .3 \mathrm{C},-\mathrm{D})$. Primary inclusions in wairakite range from $<5$ to about $75 \mu \mathrm{m}$ in diameter and are generally oval, circular, and elongate in cross section (Pl. 3E).

Primary inclusions in all sample types contain two phases, an aqueous liquid and a vapor bubble, and no daughter minerals. All primary inclusions have uniform phase ratios with the vapor bubbles comprising 5 to 20 volume percent (vol\%) of the inclusion (e.g., Plate
2A, -B, -C,-D, and 3A, -B, -C, -D, -E); on this basis, these inclusion fluids do not appear to have undergone boiling or phase separation at the site of mineral precipitation.

One primary fluid inclusion from Sample 139-858A-29X-1, 30 $32 \mathrm{~cm}$, a hydrothermally altered, fine-grained sediment with a crosscutting veinlet of anhydrite was observed to contain three phases ( $\mathrm{CO}_{2}$ vapor bubble within a $\mathrm{CO}_{2}$ liquid bubble in aqueous liquid). This is the only such inclusion of its type observed in all the samples examined and, due to its scarcity, we are unable to ascertain its origin and genetic relation to the MV hydrothermal systems.

\section{Secondary Inclusions}

Secondary inclusions comprise the majority of the inclusions present in many of the samples. Secondary inclusions generally contain two phases, an aqueous fluid and a vapor bubble, range from 1 to $>30$ $\mu \mathrm{m}$ in diameter, and are typically elongate or irregular. They occur as discontinuous planar arrays or trails along healed microfractures. Such inclusions were trapped after the brittle fracturing of the host minerals. Within a sample only one generation of secondary inclusions are present, and no cross-cutting trails of inclusions were observed. Trails of inclusions along healed microfractures were not observed to cut across grain boundaries, which suggests that fluid movement was predominantly along grain boundaries.

In certain samples, some adjacent secondary inclusions possess widely differing phase ratios. In some of these inclusions, clear evidence of necking was observed, with thin, faint hairline fractures connecting nearby inclusions. However, in other inclusions with widely different phase proportions, necking has proceeded to a greater degree, and only careful examination of both petrographic and microthermometric characteristics could be used to discern between necking and phase separation processes. Necking can result in vapor-rich inclusions, as suggested by the presence of single-phase, liquid-only inclusions (Bodnar et al., 1985). As pointed out by Bodnar et al. (1985), the presence of liquid-only inclusions in the vicinity of vapor-rich or onephase vapor inclusions indicates that necking rather than entrapment of boiling inclusion fluids occurred. The co-occurrence of adjacent liquidonly and vapor-rich inclusions along with inclusions of widely different phase ratios in the MV samples, particularly in quartz and wairakite from quartz-wairakite-epidote veins in mafic sill samples, indicates that such inclusions are the products of post-entrapment necking.

\section{Fluid Inclusion Microthermometry}

On heating of frozen inclusions, eutectic melting $\left(\mathrm{T}_{\mathrm{e}}\right)$ occurred between $-56.4^{\circ}$ and $-45.9^{\circ} \mathrm{C}$ (Fig. $4 \mathrm{~A}$ ). In many of the inclusions, eutectic melting was recognized by the inclusions suddenly becoming more translucent in places. In the smaller inclusions, it was difficult to accurately observe the onset of melting due to the small amount of melt formed at the eutectic; as a result, many of the measured values may be too high. $T_{e}$ measurements, as well as the chemical composition of vent and pore fluids (see below), suggests that the fluids might best be modeled in the $\mathrm{H}_{2} \mathrm{O}-\mathrm{NaCl}-\mathrm{CaCl}_{2}$ system (Crawford, 1981 ; Vanko et al., 1988; Oakes et al., 1990), which has a eutectic temperature $\left(\mathrm{T}_{\mathrm{e}}\right.$ ) of $-52^{\circ} \mathrm{C}$ (Fig. 5). Recorded $\mathrm{T}_{\mathrm{e}}$ temperatures below $-52^{\circ} \mathrm{C}$ are likely due to the formation of metastable phases on freezing, as metastable melting events have been shown to be common at temperatures below $-50^{\circ} \mathrm{C}$ (e.g., Vanko et al., 1988; Oakes et al., 1990; Davis et al., 1990).

Temperatures slightly lower than the eutectic are not thought to be due to the presence of other solutes such as $\mathrm{Mg}$, which are known to further depress eutectic melting temperatures (Borisenko, 1977; Crawford et al., 1979). Basalt-seawater interaction experiments indicate low $\mathrm{Mg}$ concentrations of hydrothermal fluids at high temperatures (Mottl et al., 1979; Seyfried and Bischoff, 1981), and undiluted endmember fluids from active hydrothermal vents on the seafloor are essentially 
Figure 5. Ternary plot of phase relations in the $\mathrm{H}_{2} \mathrm{O}-\mathrm{NaCl}-\mathrm{CaCl}_{2}$ system. Isotherms in the ice + liquid field are plotted from data of Oakes et al. (1990). Cotectic boundaries are from Yanatieva (1946). Shown are $\mathrm{NaCl} /\left(\mathrm{CaCl}_{2}+\mathrm{NaCl}\right)$ weight fractions for fluid inclusions obtained from final hydrohalite melting temperatures in aqueous solutions and for vent fluids from Sites 858 and 856. Inset shows enlargement of $\mathrm{H}_{2} \mathrm{O}$ apex.

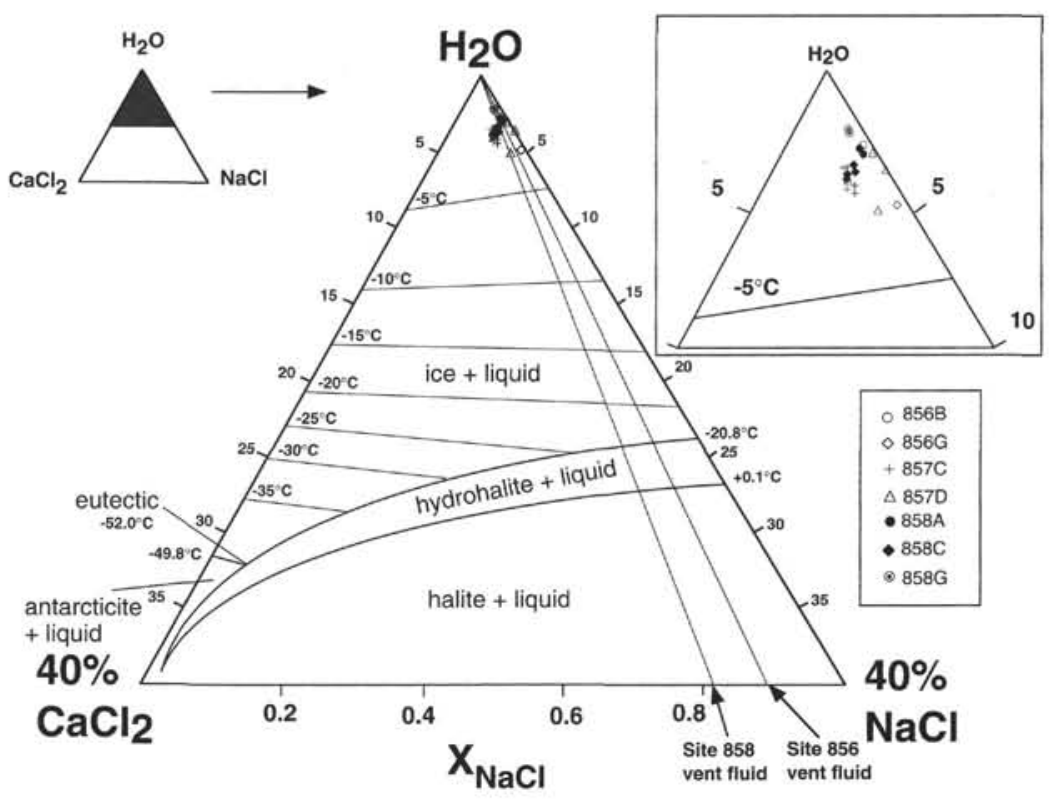

devoid of $\mathrm{Mg}$ (less than $1 \mathrm{mmol} / \mathrm{kg}$ ) as a result of extensive cation exchange between seawater and rocks in the subsurface within the downgoing (recharge) portions of the convective system (e.g., Von Damm, 1990). MV hydrothermal fluids that approach endmember compositions have only 3-6 mmol/kg Mg (Lydon et al., 1990, 1991, 1992; J.W. Lydon, unpubl. data), and endmember fluids have: 40-81 $\mathrm{mmol} / \mathrm{kg} \mathrm{Ca}, 315-398 \mathrm{mmol} / \mathrm{kg} \mathrm{Na}, 13.5-18.7 \mathrm{mmol} / \mathrm{kg} \mathrm{K}, 10-20$ $\mu \mathrm{mol} / \mathrm{kg} \mathrm{Fe}, 63-78 \mu \mathrm{mol} / \mathrm{kg} \mathrm{Mn}$, and $412-578 \mathrm{mmol} / \mathrm{kg} \mathrm{Cl}$ (Butterfield et al., this volume).

With continued slow heating, two fine-grained solid phases were visible in very few of the inclusions at low temperatures, and it was possible to measure the melting point of each of these. In order to obtain information on the relative contents of $\mathrm{Na}, \mathrm{Ca}$, and $\mathrm{H}_{2} \mathrm{O}$ in the inclusion fluids, the sequential freezing method outlined in Haynes (1985) was used on selected, larger ( 15 to $70 \mu \mathrm{m}$ diameter) inclusions. This technique involves the recooling of partly melted fluid inclusions and allowed the formation of hydrohalite $\left(\mathrm{NaCl} .2 \mathrm{H}_{2} \mathrm{O}\right)$ (which possesses a refractive index greater than ice) and ice, and the unimpeded observation of hydrohalite melting (Thh) which occurred between $-26.2^{\circ}$ and $-20.8^{\circ} \mathrm{C}$ (Fig. 4B). This allowed for the unambiguous observation of eutectic and cotectic phase equilibria (intermediate melting events) which could otherwise only rarely be observed.

Final melting of ice $\left(\mathrm{T}_{\mathrm{m}}\right)$ occurred between $-5.9^{\circ}$ and $-1.1^{\circ} \mathrm{C}$ (mean $=-2.7^{\circ} \pm 1.0^{\circ} \mathrm{C} ; n=42$ ) (Table 2 ). No evidence of clathrate melting was observed in any of the inclusions. Salinities were calculated from the temperature of final ice disappearance (freezing point depression) using the revised equation of Bodnar (1993). The temperatures of final ice melting correspond to salinities of 1.9 to 9.1 eq. wt\% $\mathrm{NaCl}$ (mean $=4.3 \pm 1.4$ eq. wt $\% \mathrm{NaCl} ; n=42$ ) (Table $2 ;$ Fig. 6). Variations in $\mathrm{T}_{\mathrm{m}}$ of low-salinity inclusions can result from differences in their gas contents because dissolved gases will also affect the freezing point depression (Hedenquist and Henley, 1985). There is a freezing point depression of $1.86^{\circ} \mathrm{C}$ per mole of $\mathrm{CO}_{2}$, and because $\mathrm{CO}_{2}$ clathrate is difficult to nucleate at low gas concentrations, the presence of $\mathrm{CO}_{2}$ may go undetected (Moore et al., 1992). However, crushing studies of several inclusions did not indicate pressures greater than atmospheric, and significant $\mathrm{CO}_{2}$ contents are not expected.

For inclusions where both $\mathrm{T}_{\mathrm{hh}}$ and $\mathrm{T}_{\mathrm{m}}$ data have been obtained, the relative ratios of $\mathrm{Na}$ to $\mathrm{Ca}$ in the inclusion fluids can be estimated (Table 2). The temperature at which hydrohalite melts defines the point at which the liquid composition leaves the cotectic and, therefore, constrains its relative $\mathrm{Na} / \mathrm{Ca}$ ratio. On further heating the liquid

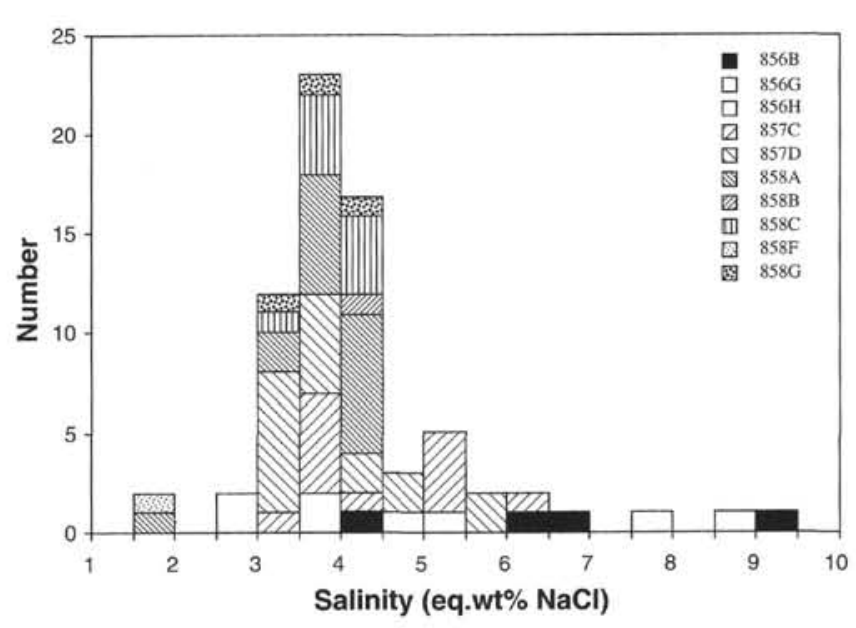

Figure 6. Frequency histogram of fluid inclusion salinities by drill hole.

composition moves toward the $\mathrm{H}_{2} \mathrm{O}$ apex (Fig. 5), and the final melting of ice determines the point at which the liquid composition leaves the liquidus and hence fixes its bulk composition. Compositions for inclusion fluids from different sites are shown in Figure 5.

Because necking can alter the volumes and masses of fluid within inclusions (e.g., Sterner and Bodnar, 1989), only microthermometric data for inclusions which showed consistent liquid to vapor ratios are presented. We are aware of the possible stretching of inclusions in minerals such as anhydrite and sphalerite during microthermometric examination (e.g., Bodnar and Bethke, 1984). However, the $T_{t}$ obtained for these minerals are similar to, or within the range determined for, other minerals such as quartz that are less susceptible to stretching, and on this basis we conclude that stretching problems were not important in this study.

Homogenization temperatures for all inclusions from all sites range from $58^{\circ}$ to $330^{\circ} \mathrm{C}\left(\right.$ mean $\left.=219^{\circ} \pm 58^{\circ} \mathrm{C}[1 \sigma] ; n=202\right)$. To obtain $\mathrm{T}_{t}$, homogenization temperatures were corrected for the effect of pressure of the overlying water and sediment column. Because the pressurevolume-temperature properties for the $\mathrm{H}_{2} \mathrm{O}-\mathrm{NaCl}-\mathrm{CaCl}_{2}$ system are not available, pressure corrections were made using the properties for the NaCl- $\mathrm{H}_{2} \mathrm{O}$ system (Potter, 1977). Potter and Brown (1977) have 
Table 2. Microthermometric data from fluid inclusions in hydrothermal precipitates from $\mathrm{MV}$ samples and $\mathrm{NaCl} / \mathrm{CaCl} 2$ weight ratios calculated from available analyses of pore fluids extracted from nearest the fluid inclusion sample (Davis, Mottl, Fisher, et al., 1992).

\begin{tabular}{|c|c|c|c|c|c|c|c|c|c|c|c|c|c|c|c|}
\hline Chip/inclusion & $\begin{array}{l}\mathrm{T}_{\mathrm{t}} \\
\left({ }^{\circ} \mathrm{C}\right)\end{array}$ & $\begin{array}{l}\mathrm{T}_{\mathrm{e}} \\
\left({ }^{\circ} \mathrm{C}\right)\end{array}$ & $\begin{array}{l}\mathrm{T}_{\text {bh }} \\
\left({ }^{\circ} \mathrm{C}\right)\end{array}$ & $\begin{array}{l}\mathrm{T}_{\mathrm{m}} \\
\left({ }^{\circ} \mathrm{C}\right)\end{array}$ & $\begin{array}{c}\text { Salinity } \\
(\text { eq. wt\% } \\
\mathrm{NaCl})\end{array}$ & $\begin{array}{c}\text { Fluid } \\
\text { inclusion } \\
\mathrm{NaCl} \mathrm{CaCl}_{2} \\
\text { weight ratio }\end{array}$ & $\begin{array}{l}\text { Pore fluid } \\
\mathrm{NaCl} / \mathrm{CaCl}_{2} \\
\text { weight ratio }\end{array}$ & Chip/inclusion & $\begin{array}{l}\mathrm{T}_{\mathrm{t}} \\
\left({ }^{\circ} \mathrm{C}\right)\end{array}$ & $\begin{array}{l}\mathrm{T}_{\mathrm{e}} \\
\left({ }^{\circ} \mathrm{C}\right)\end{array}$ & $\begin{array}{l}\mathrm{T}_{\text {hh }} \\
\left({ }^{\circ} \mathrm{C}\right)\end{array}$ & $\begin{array}{l}\mathrm{T}_{\mathrm{m}} \\
\left({ }^{\circ} \mathrm{C}\right)\end{array}$ & $\begin{array}{l}\text { Salinity } \\
\text { (eq. wt\% } \\
\mathrm{NaCl})\end{array}$ & $\begin{array}{c}\text { Fluid } \\
\text { inclusion } \\
\mathrm{NaCl} / \mathrm{CaCl}_{2} \\
\text { weight ratio }\end{array}$ & $\begin{array}{l}\text { Pore fluid } \\
\mathrm{NaCl} / \mathrm{CaCl}_{2} \\
\text { weight ratio }\end{array}$ \\
\hline \multicolumn{8}{|c|}{ Sample 139-856B-15X-2, 67-69 cm (depth: $2532.6 \mathrm{mbsl}$; host mineral: quartz) } & \multicolumn{8}{|c|}{ Sample 139-857C-62R-1, 67-69 cm (depth: $2922.4 \mathrm{mbsl}$; host mineral: quartz) } \\
\hline $1 / 1$ & 208 & & & & & & & $1 / 1$ & 269 & & & & & & \\
\hline $2 / 1$ & 338 & & & & & & & $1 / 2$ & 278 & & & & & & \\
\hline $2 / 2$ & 234 & & & & & & & $2 / 3$ & 269 & & & & & & \\
\hline $2 / 3$ & 233 & & & & & & & $3 / 1$ & 258 & & & & & & \\
\hline $3 / 1$ & 193 & & & & & & & $3 / 3$ & 262 & & & & & & \\
\hline $4 / 1$ & 235 & -47.6 & -21.2 & -2.4 & 4.0 & 6.5 & $28.7^{\mathrm{a}}$ & $3 / 4$ & 277 & & & & & & \\
\hline $5 / 1$ & 303 & & & & & & & $3 / 5$ & 271 & & & & & & \\
\hline $5 / 2$ & 217 & & & & & & & $3 / 6$ & 268 & & & & & & \\
\hline $6 / 1$ & 310 & & & & & & & $3 / 7$ & 268 & & & & & & \\
\hline $7 / 1$ & 181 & & & & & & & $3 / 8$ & 269 & & & & & & \\
\hline $7 / 3$ & 293 & & & & & & & $4 / 1$ & 258 & & & & & & \\
\hline $8 / 1$ & 294 & & & & & & & $4 / 2$ & 275 & & & & & & \\
\hline $8 / 2$ & 298 & & & & & & & $4 / 3$ & 273 & & & & & & \\
\hline $8 / 3$ & 252 & & & & & & & $4 / 4$ & 269 & & & & & & \\
\hline $11 / 1$ & 261 & & & & & & & $4 / 5$ & 272 & & & & & & \\
\hline $11 / 2$ & 255 & & & -4.1 & 6.6 & & & $4 / 6$ & 272 & & & & & & \\
\hline $12 / 1$ & 303 & & & & & & & $4 \pi$ & 275 & & & & & & \\
\hline $\begin{array}{l}12 / 2 \\
12 / 3\end{array}$ & $\begin{array}{l}320 \\
276\end{array}$ & & & & & & & \multicolumn{8}{|c|}{ Sample 139-857C-64R-2, 74-76 cm (depth: $2943.3 \mathrm{mbsl}$; host mineral: wairakite) } \\
\hline $\begin{array}{l}12 / 3 \\
12 / 4\end{array}$ & $\begin{array}{l}276 \\
267\end{array}$ & & & & & & & $1 / 1$ & 273 & & -25.1 & -2.2 & 3.7 & 2.9 & $2.7^{\mathrm{b}}$ \\
\hline $\begin{array}{l}12 / 4 \\
12 / 5\end{array}$ & 270 & & & & & & & $1 / 2$ & 274 & & & -2.2 & 3.7 & & \\
\hline $3 / 1$ & 241 & -45.9 & & -4.0 & 6.4 & & & $1 / 3$ & & & -24.9 & -2.4 & 4.0 & 2.4 & $2.7^{b}$ \\
\hline $14 / 1$ & & & -5.9 & 9.1 & & & & $1 / 4$ & & & -24.9 & -2.2 & 3.7 & 2.4 & $2.7^{b}$ \\
\hline & & & & & & & & $1 / 5$ & 299 & & -25.1 & -2.2 & 3.7 & 2.9 & $2.7^{b}$ \\
\hline \multirow{2}{*}{\multicolumn{8}{|c|}{ Sample 139-856F-2X-CC, 23-25 cm (depth: 2435.2 mbsl; host mineral: dolomite) }} & $3 / 1$ & 261 & & -25.3 & -3.0 & 5.0 & 3.0 & $2.7^{\circ}$ \\
\hline $1 / 1$ & & & & & & & & $3 / 2$ & 210 & & & -3.9 & 6.3 & & \\
\hline $1 / 2$ & 204 & & & & & & & $3 / 3$ & & & & -3.2 & 5.3 & & \\
\hline $2 / 1$ & 231 & & & & & & & $3 / 4$ & 268 & & -25.1 & -3.0 & 5.0 & 2.9 & $2.7^{b}$ \\
\hline $2 / 2$ & 242 & & & & & & & $3 / 5$ & 268 & & -25.1 & -3.0 & 5.0 & 2.9 & $2.7^{b}$ \\
\hline $3 / 1$ & 226 & & & & & & & $3 / 7$ & 306 & & & & & & \\
\hline $3 / 2$ & 218 & & & & & & & Sample 139-857 & D-1R- & 1,137 & $-139 \mathrm{~cm}$ & $\mathrm{n}$ (dept & h: $3003.6 \mathrm{~m}$ & bsl; host mine & ral: quartz) \\
\hline Sample 139-856 & $\mathrm{G}-7 \mathrm{R}$ - & $-4,4-6$ & $\mathrm{~cm}$ (der) & pth: 24 & $22.8 \mathrm{mbsl} ;$ & host mineral: s & phalerite) & $1 / 1$ & 273 & & & & (1) & (2) & \\
\hline $2 / 1$ & & & & -5.0 & 7.9 & & & $1 / 2$ & 267 & & & & & & \\
\hline $6 / 1$ & 260 & & & & & & & $1 / 3$ & 273 & & & & & & \\
\hline $6 / 1$ & 260 & & & & & & & $2 / 1$ & 272 & & & & & & \\
\hline $7 / 1$ & 253 & & & & & & & $2 / 2$ & 268 & & & & & & \\
\hline $8 / 1$ & 266 & & & & & & & $2 / 3$ & 278 & & & & & & \\
\hline $9 / 1$ & 241 & & & & & & & $2 / 4$ & 272 & & & & & & \\
\hline $9 / 2$ & & & & -2.2 & 3.7 & & & $2 / 5$ & 270 & & & & & & \\
\hline $9 / 3$ & & -45.5 & -22.6 & -3.2 & 5.3 & 5.6 & NA & $2 / 6$ & 268 & & & & & & \\
\hline $9 / 4$ & & & & -2.2 & 3.7 & & & $2 / 7$ & 268 & & & & & & \\
\hline $\begin{array}{l}9 / 5 \\
9 / 6\end{array}$ & $\begin{array}{l}277 \\
278\end{array}$ & & & & & & & Sample 139-857. & D-11R & $2-1,1-$ & $3 \mathrm{~cm}(\mathrm{de}$ & lepth: 3 & $100.6 \mathrm{mbsl} ;$ & ; host mineral: & quartz) \\
\hline $9 / 7$ & 267 & & & & & & & $2 / 1$ & 276 & & & & & & \\
\hline $9 / 8$ & 262 & & & & & & & $2 / 2$ & 278 & & & & & & \\
\hline $9 / 9$ & 276 & & & & & & & $2 / 3$ & 248 & & & & & & \\
\hline $10 / 1$ & 259 & & & & & & & $2 / 4$ & 271 & & & & & & \\
\hline $10 / 2$ & 209 & & & & & & & $2 / 5$ & 250 & & & & & & \\
\hline & & & & & & & & $2 / 6$ & 256 & & & & & & \\
\hline $\begin{array}{c}\text { Sample 139-856 } \\
1 / 1\end{array}$ & $\mathrm{H}-3 \mathrm{R}-$ & $-2,16-1$ & $18 \mathrm{~cm}($ & depth: & $2447.2 \mathrm{mbs}$ & st; host mineral & 1: dolomite) & $2 \pi$ & 258 & & & & & & \\
\hline $\begin{array}{l}1 / 1 \\
2 / 1\end{array}$ & 207 & & & & & & & $2 / 8$ & 254 & & & & & & \\
\hline $\begin{array}{l}2 / 1 \\
3 / 1\end{array}$ & 171 & & & & & & & $2 / 9$ & 267 & & & & & & \\
\hline $\begin{array}{l}3 / 1 \\
6 / 1\end{array}$ & $\begin{array}{l}161 \\
154\end{array}$ & & & & & & & $2 / 10$ & $\begin{array}{l}267 \\
278\end{array}$ & & & & & & \\
\hline $\begin{array}{l}6 / 1 \\
6 / 2\end{array}$ & $\begin{array}{l}154 \\
158\end{array}$ & & & & & & & $\begin{array}{l}2 / 11 \\
2 / 12\end{array}$ & $\begin{array}{l}278 \\
285\end{array}$ & & & & & & \\
\hline $0 / 2$ & 150 & & & & & & & $2 / 13$ & 249 & & & & & & \\
\hline Sample $139-856$ & $6 \mathrm{H}-3 \mathrm{R}-$ & $-2,84-8$ & $87 \mathrm{~cm}($ & depth: 2 & $2447.9 \mathrm{mbs}$ & il; host mineral & I: dolomite) & $2 / 14$ & 280 & & & & & & \\
\hline $1 / 1$ & 172 & & & & & & & $2 / 15$ & 259 & & & & & & \\
\hline $2 / 1$ & 164 & & & & & & & $2 / 16$ & 271 & & & & & & \\
\hline $2 / 2$ & 169 & & & -5.5 & 8.5 & & & $2 / 17$ & 268 & & & & & & \\
\hline $3 / 1$ & 176 & -56.0 & & -1.7 & 2.9 & & & $2 / 18$ & 255 & & & & & & \\
\hline $3 / 2$ & 198 & & & -1.6 & 2.7 & & & $2 / 19$ & 270 & & & & & & \\
\hline $5 / 1$ & 174 & & & & & & & $2 / 20$ & 281 & & & & & & \\
\hline $5 / 2$ & 185 & -46.3 & & -2.8 & 4.6 & & & $2 / 21$ & 268 & & & & & & \\
\hline $5 / 3$ & 169 & & & & & & & $2 / 22$ & 278 & & & & & & \\
\hline Sample 139-85 & C- $-60 \mathrm{R}$ & $-2,28$ & $-30 \mathrm{~cm}$ & (depth: & : $2904.2 \mathrm{mb}$ & ssl; host miner & al: quartz) & $2 / 23$ & 269 & & & -2.2 & 3.7 & & \\
\hline Sampie 1.59-03 & $(-00 \mathrm{k}$ & $\begin{array}{ll}-2,20- \\
-495\end{array}$ & $-30 \mathrm{~cm}$ & (depto: & $.2904 .2 \mathrm{mo}$ & osi, nost miner & ar: quatrz) & $2 / 24$ & 264 & & & -3.5 & 5.7 & & \\
\hline $1 / 1$ & & -49.5 & & -1.8 & 3.1 & & & $2 / 25$ & & -46.5 & & -1.8 & 3.1 & & \\
\hline $1 / 2$ & & & & -2.1 & 3.5 & & & $2 / 26$ & & -48.8 & & -1.8 & 3.1 & & \\
\hline $1 / 3$ & & -50.6 & & & & & & $2 / 27$ & & -48.1 & & -1.8 & 3.1 & & \\
\hline Sample 139-85 & 7C-61R & $2,2,4-6$ & $6 \mathrm{~cm}(\mathrm{~d}$ & epth: 29 & $913.6 \mathrm{mbsl}$; & ; host mineral: & quartz) & Sample 139-857 & $7 D-12 R$ & $2-1,88$ & $-90 \mathrm{~cm}$ & (depth & $: 3107.4 \mathrm{mb}$ & osl; host miner & al: wairakite) \\
\hline $1 / 1$ & 268 & & & & & & & $3 / 9$ & & & & -2.8 & 4.6 & & \\
\hline $1 / 2$ & 263 & & & & & & & $3 / 10$ & & -56.4 & & -2.8 & 4.6 & & \\
\hline $1 / 3$ & 244 & & & & & & & $4 / 5$ & 311 & & & & & & \\
\hline $1 / 4$ & 244 & & & & & & & $4 / 8$ & 294 & & & & & & \\
\hline
\end{tabular}


Table 2 (continued).

\begin{tabular}{|c|c|c|c|c|c|c|c|}
\hline Chip/inclusion & $\begin{array}{c}\mathrm{T}_{\mathrm{t}} \\
\left({ }^{\circ} \mathrm{C}\right)\end{array}$ & $\begin{array}{l}\mathrm{T}_{\mathrm{e}} \\
\left({ }^{\circ} \mathrm{C}\right)\end{array}$ & $\begin{array}{l}\mathrm{T}_{\text {hh }} \\
\left({ }^{\circ} \mathrm{C}\right)\end{array}$ & $\begin{array}{l}\mathrm{T}_{\mathrm{m}} \\
\left({ }^{\circ} \mathrm{C}\right)\end{array}$ & $\begin{array}{c}\text { Salinity } \\
(\mathrm{eq}, \mathrm{wt} \% \\
\mathrm{NaCl})\end{array}$ & $\begin{array}{c}\text { Fluid } \\
\text { inclusion } \\
\mathrm{NaCl} / \mathrm{CaCl}_{2} \\
\text { weight ratio }\end{array}$ & $\begin{array}{c}\text { Pore fluid } \\
\mathrm{NaCl} / \mathrm{CaCl}_{2} \\
\text { weight ratio }\end{array}$ \\
\hline $4 / 10$ & 307 & & & & & & \\
\hline $6 / 2$ & 350 & & & & & & \\
\hline $6 / 3$ & 314 & & & & & & \\
\hline $6 / 6$ & 275 & & & & & & \\
\hline $7 / 1$ & 292 & & & & & & \\
\hline $8 / 4$ & 318 & -47.2 & -23.5 & -3.4 & 5.6 & 3.3 & $6.6^{\mathrm{c}}$ \\
\hline $9 / 5$ & 281 & & & & & & \\
\hline $10 / 1$ & & & -26.2 & -2.6 & 4.3 & 1.5 & $6.6^{\mathrm{c}}$ \\
\hline $10 / 2$ & & & -22.9 & & & 4.5 & $6.6^{\mathrm{c}}$ \\
\hline $10 / 5$ & & & & -2.2 & 3.7 & & \\
\hline $10 / 6$ & & & & -2.0 & 3.4 & & \\
\hline $10 / 7$ & & & & -2.2 & 3.7 & & \\
\hline $10 / 9$ & & & & -2.0 & 3.4 & & \\
\hline $10 / 11$ & 242 & & & & & & \\
\hline $10 / 12$ & & & & -2.0 & 3.4 & & \\
\hline $11 / 1$ & 283 & & & & & & \\
\hline $12 / 1$ & & -50.2 & -20.8 & -2.5 & 4.2 & 100 & $6.6^{\mathrm{c}}$ \\
\hline $12 / 2$ & & -50.6 & -21.0 & -2.2 & 3.7 & 7.0 & $6.6^{c}$ \\
\hline \multirow{2}{*}{\multicolumn{8}{|c|}{ Sample 139-858A-28X-CC, $4-5 \mathrm{~cm}$ (depth: $2649.0 \mathrm{mbsl}$; host mineral: anhydrite) }} \\
\hline & & & & & & & \\
\hline $1 / 2$ & 255 & & & & & & \\
\hline $1 / 3$ & 283 & & & & & & \\
\hline $1 / 4$ & 251 & & & & & & \\
\hline $1 / 5$ & 269 & & & & & & \\
\hline \multicolumn{8}{|c|}{ Sample 139-858A-29X-1, 30-32 cm (depth: $2663.1 \mathrm{mbsl}$; host mineral: anhydrite) } \\
\hline $1 / 1$ & 236 & & & & & & \\
\hline $1 / 2$ & 255 & & & & & & \\
\hline $1 / 3$ & 231 & & & & & & \\
\hline $1 / 4$ & 264 & & & & & & \\
\hline $1 / 5$ & 259 & & & & & & \\
\hline $1 / 6$ & 230 & & & & & & \\
\hline $1 / 7$ & 254 & & & & & & \\
\hline $1 / 8$ & 257 & & & & & & \\
\hline $1 / 9$ & 259 & & & & & & \\
\hline $2 / 1$ & & -47.5 & -22.2 & -2.2 & 3.7 & 5.4 & $4.6^{\mathrm{d}}$ \\
\hline $3 / 1$ & 265 & -48.1 & -22.3 & -2.6 & 4.3 & 5.3 & $4.6^{\mathrm{d}}$ \\
\hline
\end{tabular}

Sample 139-858B-2H-3, 113-115 cm (depth: 2421.0 mbsl; host mineral: anhydrite)

$\begin{array}{ll}1 / 1 & 152 \\ 2 / 1 & 141 \\ 2 / 2 & 139 \\ 2 / 3 & 149 \\ 2 / 4 & 137 \\ 2 / 5 & 139 \\ 3 / 1 & 167\end{array}$

Sample 139-858B-2H-4, 43-45 cm (depth: 2423.0 mbsl; host mineral: anhydrite) $\begin{array}{ll}1 / 1 & 138 \\ 1 / 2 & 90\end{array}$

Sample 139-858C-3H-1, 78-81 cm (depth: 2430.7 mbsl; host mineral: calcite) $\begin{array}{ll}1 / 1 & 204 \\ 1 / 2 & 186 \\ 2 / 1 & 298\end{array}$

Sample 139-858C-3H-1, 145-150 cm (depth: 2431.3 mbsl; host mineral: calcite) $\begin{array}{ll}1 / 1 & 137 \\ 1 / 2 & 138 \\ 1 / 3 & 138\end{array}$

shown that the errors resulting from this approximation are very small. A correction ranging between $10^{\circ}$ and $36^{\circ} \mathrm{C}$ for a 5 eq. wt $\% \mathrm{NaCl}$ solution must be added to the homogenization temperatures, assuming hydrostatic conditions for the samples which were collected at depths between 2421.0 and 3107.4 mbsl. Calculated $T_{t}$ for inclusions from all sites range between $90^{\circ}$ and $350^{\circ} \mathrm{C}\left(\right.$ mean $\left.=240^{\circ} \pm 52^{\circ} \mathrm{C}[1 \sigma] ; n=202\right)$ (Fig. 7A). There is a bimodal distribution of $\mathrm{T}_{t}$ (Fig. 7A). The lower temperature group represents inclusions in carbonate concretions and anhydrite from the low-temperature alteration zones and from dolomite interstitial to massive sulfide, and the higher temperature group is from inclusions in minerals co-precipitated with sulfides and/or from the high-temperature upflow zones (see Goodfellow and Peter, this volume). Fig. 7B-D gives frequency distributions of $\mathrm{T}_{\mathrm{t}}$ for Sites 856 , 857 , and 858 , respectively.

\begin{tabular}{|c|c|c|c|c|c|c|c|}
\hline Chip/inclusion & $\begin{array}{c}\mathrm{T}_{\mathrm{t}} \\
\left({ }^{\circ} \mathrm{C}\right)\end{array}$ & $\begin{array}{c}\mathrm{T}_{\mathrm{e}} \\
\left({ }^{\circ} \mathrm{C}\right)\end{array}$ & $\begin{array}{l}\mathrm{T}_{\mathrm{hh}} \\
\left({ }^{\circ} \mathrm{C}\right)\end{array}$ & $\begin{array}{l}\mathrm{T}_{\mathrm{m}} \\
\left({ }^{\circ} \mathrm{C}\right)\end{array}$ & $\begin{array}{c}\text { Salinity } \\
\text { (eq. wt\% } \\
\mathrm{NaCl})\end{array}$ & $\begin{array}{c}\text { Fluid } \\
\text { inclusion } \\
\mathrm{NaCl} / \mathrm{CaCl}_{2} \\
\text { weight ratio }\end{array}$ & $\begin{array}{c}\text { Pore fluid } \\
\mathrm{NaCl} / \mathrm{CaCl}_{2} \\
\text { weight ratio }\end{array}$ \\
\hline $1 / 4$ & 140 & & & & & & \\
\hline $1 / 5$ & 112 & & & & & & \\
\hline $1 / 6$ & 150 & & & & & & \\
\hline $2 / 1$ & 134 & & & & & & \\
\hline $2 / 2$ & 128 & & & & & & \\
\hline $2 / 3$ & 134 & & & & & & \\
\hline $2 / 4$ & 119 & & & & & & \\
\hline \multicolumn{8}{|c|}{ Sample 139-858C-3H-2, 10-15 cm (depth: $2431.5 \mathrm{mbsl}$; host mineral: calcite) } \\
\hline $1 / 1$ & 192 & & & & & & \\
\hline $2 / 1$ & 165 & & & & & & \\
\hline $3 / 1$ & 184 & & & & & & \\
\hline $3 / 2$ & 175 & & & & & & \\
\hline $4 / 1$ & 135 & & & & & & \\
\hline $5 / 1$ & 137 & & & & & & \\
\hline $5 / 2$ & 126 & & & & & & \\
\hline $5 / 3$ & 146 & & & & & & \\
\hline \multicolumn{8}{|c|}{ Sample 139-858C-3H-3, 22-24 cm (depth: $2433.1 \mathrm{mbsl}$; host mineral: calcite) } \\
\hline $1 / 1$ & 236 & & & -2.1 & 3.5 & & \\
\hline $1 / 2$ & 235 & & & & & & \\
\hline $1 / 3$ & 242 & & & -2.0 & 3.4 & & \\
\hline $1 / 4$ & 230 & & & & & & \\
\hline $1 / 5$ & 230 & & & & & & \\
\hline $1 / 6$ & 240 & & & & & & \\
\hline $1 / 7$ & 227 & & & & & & \\
\hline $2 / 1$ & 247 & & & -2.6 & 4.3 & & \\
\hline $2 / 2$ & 232 & & & & & & \\
\hline $2 / 3$ & 233 & & & & & & \\
\hline $2 / 4$ & 235 & & & -2.1 & 3.5 & & \\
\hline $2 / 5$ & 234 & & -24.1 & -2.3 & 3.9 & 3.1 & $21.1^{\mathrm{e}}$ \\
\hline $2 / 6$ & 233 & & & -2.2 & 3.7 & & \\
\hline $3 / 1$ & 232 & & -26.0 & -2.4 & 4.0 & 2.2 & $21.1^{\mathrm{e}}$ \\
\hline $3 / 2$ & 219 & & -26.0 & -2.5 & 4.2 & 2.2 & $21.1^{\mathrm{e}}$ \\
\hline $3 / 3$ & 218 & & & & & & \\
\hline $3 / 4$ & 233 & & " & & & & \\
\hline $4 / 1$ & & -48.2 & -23.9 & -2.4 & 4.0 & 3.2 & $21.1^{\mathrm{e}}$ \\
\hline \multicolumn{8}{|c|}{ Sample 139-858F-2R-CC, 8-11 cm (depth: 2452.1 mbsl; host mineral: wairakite) } \\
\hline $1 / 1$ & 280 & & & & & & \\
\hline $1 / 2$ & 283 & -46.0 & -21.9 & & & 6.0 & $5.1^{f}$ \\
\hline $1 / 3$ & 283 & & & & & & \\
\hline $1 / 4$ & 274 & & & & & & \\
\hline $1 / 5$ & 279 & & & & & & \\
\hline $1 / 6$ & 288 & & & & & & \\
\hline $1 / 7$ & 270 & & & & & & \\
\hline $1 / 8$ & & & & -1.1 & 1.9 & & \\
\hline \multicolumn{8}{|c|}{ Sample 139-858G-16R-1, 77-79 cm (depth: 2838.8 mbsl; host mineral: quartz) } \\
\hline $1 / 1$ & 293 & & -22.7 & -2.0 & 3.4 & 4.3 & NA \\
\hline $1 / 2$ & 316 & -48.1 & -22.3 & -2.1 & 3.5 & 5.3 & NA \\
\hline $1 / 3$ & 285 & & & -2.5 & 4.2 & & \\
\hline $1 / 4$ & 287 & & & & & & \\
\hline $1 / 5$ & & -47.1 & & & & & \\
\hline $1 / 6$ & 250 & & & & & & \\
\hline
\end{tabular}

Note: $\mathrm{NA}=$ not analyzed.

a Calculated from sample IW-20.

b Calculated from sample IW-3.

c Calculated from sample G-5.

d Calculated from sample IW-23.

c Calculated from sample IW-6.

${ }^{\mathrm{f}}$ Calculated from sample IW-1.

\section{DISCUSSION}

\section{Comparison of Fluid Inclusion Data With Presently Venting Fluids and Pore Fluids}

\section{Temperature}

For Site 858 (AAV), fluid inclusions in minerals from the hightemperature alteration zone (Fig. 7D) have T, between about $220^{\circ}$ and $316^{\circ} \mathrm{C}$, which are in general agreement with venting hydrothermal fluids ( $184^{\circ}$ and $276^{\circ} \mathrm{C}$ ) measured with $A L V I N ' s$ thermocouple probe (Goodfellow et al., 1994). At Site 857, $\mathrm{T}_{\text {t }}$ range between $210^{\circ}$ and $350^{\circ} \mathrm{C}$ and have a mean of $272^{\circ} \pm 19^{\circ} \mathrm{C}(1 \sigma)$. This mean temperature is very similar to the maximum measured temperature of $276^{\circ} \mathrm{C}$ for vent fluids from Site 858, supporting the interpretation that the hydro- 

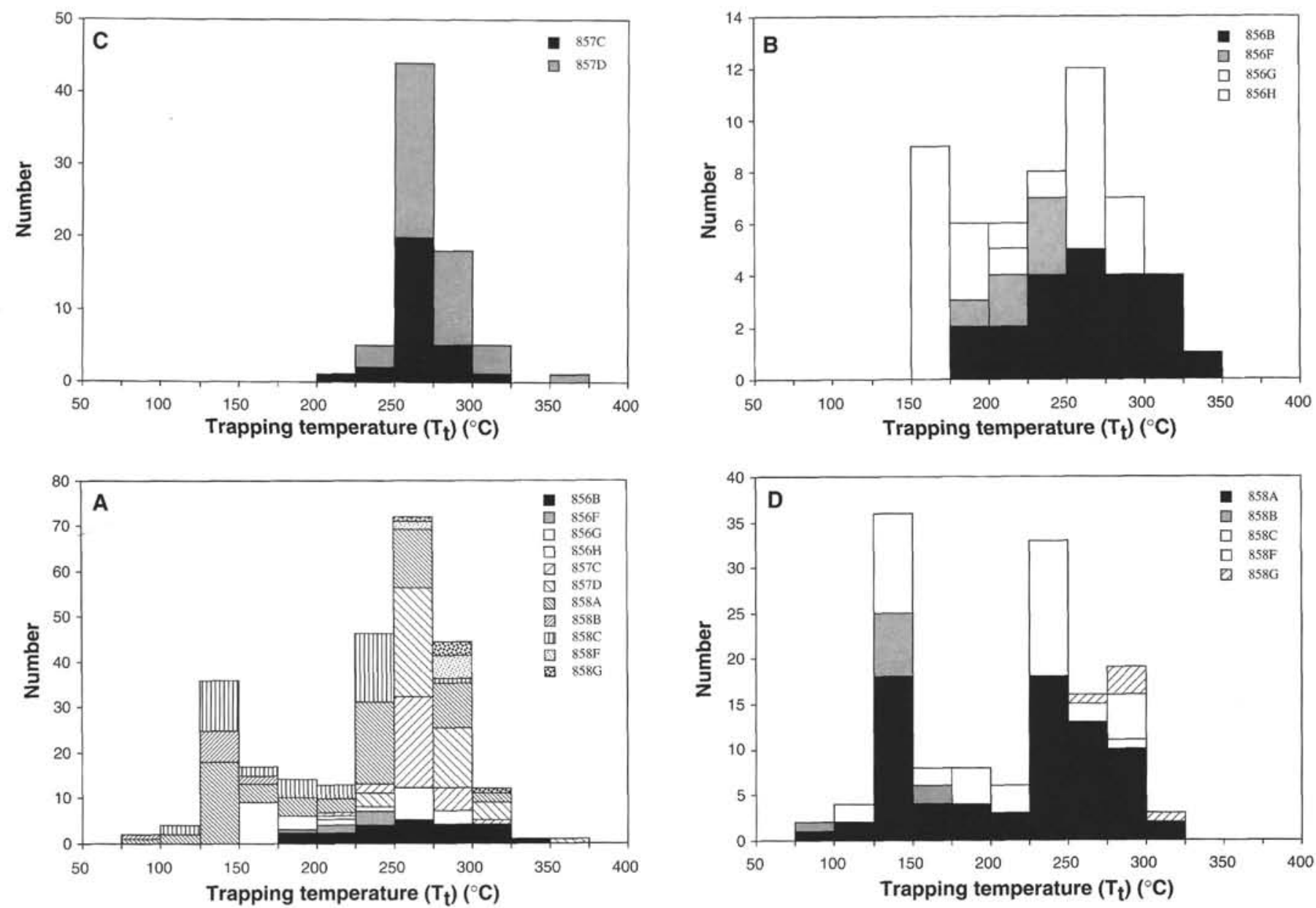

Figure 7. Frequency histograms of fluid inclusion trapping temperature by drill holes. A. All data from all sites. B. Holes $856 \mathrm{~B},-\mathrm{G}$, and $-\mathrm{H}$. C. Holes $857 \mathrm{C}$ and -D. D. Holes $858 \mathrm{~A}-\mathrm{F}$.

thermal fluids at Sites 857 and 858 are part of one hydrothermal circulation system, based on geochemical (Goodfellow and Peter, this volume) and mineralogical (Leybourne and Goodfellow, this volume) considerations. The majority of fluid inclusion temperature measurements in wairakite from Holes $857 \mathrm{C}, 857 \mathrm{D}$, and $858 \mathrm{~F}$ are well above $260^{\circ} \mathrm{C}$ (Table 2) and are within the stability field for wairakite and above the temperature at which laumontite reversibly dehydrates to form wairakite $\left(231^{\circ} \mathrm{C}\right.$ at 500 bars $\mathrm{pH}_{2} \mathrm{O}$; Liou, 1971).

$\mathrm{T}_{\mathrm{t}}$ in quartz from the high-temperature alteration zone (Goodfellow and Peter, this volume) at Site 856 range up to $338^{\circ} \mathrm{C}$. Massive sulfides from Site 856 are predominantly composed of pyrite, pyrrhotite, sphalerite, chalcopyrite/isocubanite, and magnetite. Although sphalerite is dominantly high-Fe (Goodfellow and Franklin, in press; Zierenberg, this volume) and unsuitable for fluid inclusion studies due to its opacity, $T_{t}$ obtained from late-stage, low-Fe sphalerite range between $209^{\circ}$ and $278^{\circ} \mathrm{C}$. The higher temperatures obtained for the quartz indicate that this mineral may have been precipitated with main stage sulfides, whereas the lower temperature sphalerite likely was precipitated during the waning stages of hydrothermal circulation, and these inclusions may record an overprinting of the originally deposited high-temperature sulfide assemblage at Site 856 . The temperatures obtained from the sphalerite span the $264^{\circ} \mathrm{C}$ measured temperature of fluids actively venting from anhydrite chimneys about $330 \mathrm{~m}$ south of the southern flank of BH (Fig. 2; Davis, Mottl, Fisher, et al., 1992) and $\mathrm{T}_{1}$ of $265^{\circ} \mathrm{C}$ obtained from anhydrite in chimneys from this site (Lcitch, 1991). Therefore, the inclusions in the low-Fe sphalerite may have trapped similar fluids to those now venting at Sites 858 and 856 .

\section{Salinity}

Salinities of vent fluids and pore fluids were calculated from the data of Butterfield et al. (this volume) using the empirical relation between salinity $(\mathrm{S})$ and chlorinity $(\mathrm{Cl}): \mathrm{S}(\%)=0.03+1.805 \mathrm{Cl}(\%)$ (Gerard, 1966). The average calculated salinity for Site 858 vent fluids ( 3.7 eq. wt $\% \mathrm{NaCl}$ ) is greater than normal $\mathrm{MV}$ bottom seawater ( 3.55 eq. wt\% NaCl; Davis, Mottl, Fisher, et al., 1992, p. 198). For Site 856 vent fluids, the calculated salinity of 2.6 eq. wt $\% \mathrm{NaCl}$ is below normal bottom seawater. Calculated pore fluid salinities from all sites range between 3.4 and 3.9 eq. wt $\% \mathrm{NaCl}$ and are similar to normal MV bottom seawater, although they range to higher values. Most fluid inclusion salinities are between 2.5 and 5.5 eq. wt $\% \mathrm{NaCl}$ (Fig. 6), and are in general agreement with the calculated salinities for vent fluids from Sites 858 and 856, pore fluid, and ambient bottom seawater. There is no observable relationship between salinity and depth, between $T_{t}$ and salinity, or between $T_{e}$ and $T_{t}$, which would suggest mixing between a low-salinity fluid (modified seawater) and a highly saline magmatic fluid (e.g., Shinohara et al., 1984, 1989). Salinities greater than seawater may result from the reaction of circulating seawater with subsurface sediments and the formation of hydrated clays and chlorite, where the salinity of the residual fluid is increased over seawater. 


\section{Cation Content and Ca Enrichment}

Because $\mathrm{Na}$ and $\mathrm{Ca}$ are the only major cations in the vent fluids (Fe and $\mathrm{Mn}$ are insignificant: $\mathrm{Fe}=10$ to $20 \mu \mathrm{mol} / \mathrm{kg}$ and $\mathrm{Mn}=63$ to $78 \mu \mathrm{mol} / \mathrm{kg}$; Butterfield et al., this volume), it is appropriate to compare the $\mathrm{NaCl} / \mathrm{CaCl}_{2}$ ratios of the vent fluids with those inferred for the fluid inclusions. Inclusion fluid $\mathrm{NaCl} / \mathrm{CaCl}_{2}$ weight ratios estimated from Figure 5 are 5.3 and 5.4 for Hole $858 \mathrm{~A} ; 2.2$ and 3.2 in Hole $858 \mathrm{C}$; 6.0 for Hole $858 \mathrm{~F} ; 4.3$ and 5.3 for Hole $858 \mathrm{G}$; between 2.4 and 3.0 for Hole $857 \mathrm{C}$; between 1.5 and 7.0 (except for one high value) for Hole $857 \mathrm{D}$; 6.5 for Hole $856 \mathrm{~B}$; and 5.6 for Hole $856 \mathrm{G}$ (Table 2). $\mathrm{NaCl} / \mathrm{CaCl}_{2}$ weight ratios for endmember vent fluids from MV (i.e., fluids in which the effects of admixed seawater have been removed by extrapolating to zero $\mathrm{Mg}$ content) are similar (Site 858: $\mathrm{Na}=398 \mathrm{mmol} / \mathrm{kg}$ and $\mathrm{Ca}=81 \mathrm{mmol} / \mathrm{kg}$, giving a ratio of 4.5 ; Site $856: \mathrm{Na}=315 \mathrm{mmol} / \mathrm{kg}$ and $\mathrm{Ca}=40 \mathrm{mmol} / \mathrm{kg}$, giving a ratio of 7.2 ) to those estimated from fluid inclusions and the ratio for MV bottom seawater (41.8; calculated from Davis, Mottl, Fisher, et al., 1992, p. 198-199) and, except for several samples, MV pore fluids calculated from analyses in Davis, Mottl, Fisher, et al. (1992) for fluid nearest the fluid inclusion sample (1.5 to 7.0; Table 2). The similarity of the ratios for the inclusion fluids and vent and pore fluids indicates negligible variation in $\mathrm{Ca}$ and $\mathrm{Na}$ contents of the hydrothermal fluids at least since the precipitation of most sulfides to the present.

For comparison, the $\mathrm{NaCl} / \mathrm{CaCl}_{2}$ weight ratios for endmember hydrothermal fluids from Guaymas Basin, a sedimented rift hydrothermal site in the Gulf of California (Peter and Scott, 1988; Peter and Scott, 1991), are higher than MV vent fluids (11.4 to 16.4) but are low compared to seawater (Von Damm and Bischoff, 1987). However, the $\mathrm{NaCl} / \mathrm{CaCl}_{2}$ weight ratios for endmember hydrothermal fluids from nonsedimented sites are similar to those from MV: 7.2 to 9.3 for southern Juan de Fuca Ridge (calculated from Von Damm and Bischoff, 1987) and 9.5 to 10.0 for $13^{\circ} \mathrm{N}$ East Pacific Rise (EPR) (calculated from Michard et al., 1984). EPR endmember fluids from the nonsedimented site at $21^{\circ} \mathrm{N}$ are, however, much higher than those from MV (22.6 to 34.9; calculated from Von Damm et al., 1985). Thus, MV inclusions are relatively more $\mathrm{Ca}$-rich than modern black smoker fluids from all measured vent fluids.

Basalts have been shown to constitute a source for $\mathrm{Ca}^{2+}$ to the interstitial pore fluids of the overlying sediments at certain seafloor hydrothermal systems (e.g., Lawrence et al., 1975; Gieskes and Lawrence, 1981; Lawrence and Gieskes, 1981). Vanko et al. (1992) proposed that the $\mathrm{Ca}$ contents of inclusion fluids in plutonic rocks from the MidAtlantic Ridge were modified by the albitization of plagioclase at greenschist facies conditions at very low water/rock ratios (w/r). Such a process may also explain the higher $\mathrm{Ca}$ contents of the MV inclusion fluids whereby plagioclase in the subsurface sediments are albitized to produce $\mathrm{Ca}$-enriched, $\mathrm{Mg}$-depleted, low-pH fluids capable of precipitating epidote and wairakite. Indeed, Leybourne and Goodfellow (this volume) show that significant albitization of plagioclase has occurred in the altered sediments, and Goodfellow and Peter (this volume) point out the high-Ca activity of the fluids at AAV, based on thermochemical modeling of the fluid compositions. Although there are only limited data for inclusions from Site 856, these inclusion fluids (and vent fluids) appear to be less calcic than those from Sites 858 and 857 (Fig. 5 ), and this may be due to differing $w / r$ between these sites.

\section{Comparison of Fluid Inclusion Data from Sites 856,857 , and 858}

$\mathrm{T}_{\text {t }}$ for Site $857\left(210^{\circ}\right.$ to $350^{\circ} \mathrm{C}$; mean $\left.=272^{\circ} \pm 19^{\circ} \mathrm{C}[1 \sigma] ; n=74\right)$ and for high-temperature inclusions from Site $858\left(218^{\circ}\right.$ to $316^{\circ} \mathrm{C}$; mean $\left.=255^{\circ} \pm 25^{\circ} \mathrm{C}[1 \sigma] ; n=44\right)$ are similar. Fluid inclusion salinities from the high-temperature population at Site 858 (1.9 to $4.3 \mathrm{eq}$. $\mathrm{wt} \% \mathrm{NaCl}$; mean $=3.7 \pm 0.6$ eq. $\mathrm{wt} \% \mathrm{NaCl}[1 \sigma] ; n=15)$ are within the range of inclusion salinities from Site 857 , although the latter extend to higher salinities ( 3.1 to 6.3 eq. $w t \% \mathrm{NaCl}$; mean $=4.1 \pm 0.9$ eq. $\mathrm{wt} \% \mathrm{NaCl}[1 \sigma] ; n=28$ ). These similarities suggest a common origin for the fluids at these two sites, a conclusion also supported by the similarities between the high temperature alteration mineralogy of these two sites (Leybourne and Goodfellow, this volume) and by location of these sites along the same axis-parallel thermal anomaly (Davis and Villinger, 1992). The slightly higher mean temperature and salinity for Site 857 may indicate that the fluids at this site have mixed less with seawater and more closely approach endmember compositions. This is consistent with the more Ca-rich chemistry of wairakite at Site 857 (Leybourne and Goodfellow, this volume). $\mathrm{T}_{\mathrm{t}}$ for quartz and sphalerite at Site 856 (Fig. 7B) are similar to temperatures from Sites 857 and 858 . Salinities from Site 856 (2.7 to 9.1 eq. wt $\% \mathrm{NaCl}$; mean $=5.5 \pm 2.2$ eq. wt $\% \mathrm{NaCl}[1 \theta] ; n=12$ ) are slightly higher than those for Sites 857 and 858; however, these fluid inclusion data for authigenic quartz at Site 856 are from a mineral which may be cogenetic with main-stage sulfide deposition, whereas fluid inclusion data from dolomite and low-iron sphalerite likely represent later, lower temperature fluids perhaps similar to those presently venting at Site 858 .

\section{Relationship Between Fluid Inclusion Temperatures and Depth}

For all sites, there is a general trend of increasing minimum $T_{t}$ with increasing sample depth of about $9^{\circ} \mathrm{C}$ per $100 \mathrm{~m}$ (Fig. 8). Such a trend is not due solely to a normal geothermal gradient. Figure 8 shows that for all sites, there is a relatively constant maximum temperature of around $320^{\circ} \mathrm{C}$. Furthermore, below about $2650 \mathrm{mbsl}$ inclusions have a relatively consistent minimum temperature of around $230^{\circ}$ to $240^{\circ} \mathrm{C}$. This indicates that within the core of the upflow zone, endmember fluids were heated to a temperature of around $320^{\circ} \mathrm{C}$ by cooling subsurface magmatic sills and/or other intrusive bodies before buoyantly traveling to the seafloor. Cold seawater is drawn down into the subsurface and mixes with the endmember fluids, thereby reducing the temperature of the mixture. This temperature reduction is greatest nearest the seafloor and decreases consistently to a maximum depth of around $2650 \mathrm{mbsl}$. Below this depth, significantly less seawater mixes with the endmember fluids. For these samples, lower temperatures may have resulted from conductive cooling and adiabatic expansion in addition to entrainment of seawater. Maximum fluid inclusion temperatures of around $320^{\circ} \mathrm{C}$ at Site 857 are slightly higher than the calculated maximum value of $280^{\circ} \mathrm{C}$ of Davis and Wang (this volume). These authors indicate that temperatures were never higher than those presently venting; however, fluid inclusions indicate that fluids were hotter in the past than those presently venting in MV by about $40^{\circ} \mathrm{C}$.

\section{Carbon and Oxygen Isotope Composition of Hydrothermal Fluid}

Baker et al. (this volume) present carbon and oxygen isotope data for hydrothermal carbonates from MV, and these data are not discussed in detail here. However, the combined use of $T_{t}$ obtained from fluid inclusions for dolomite and calcite, and carbon and oxygen isotope compositions of those same samples, allows the calculation of the carbon and oxygen isotope compositions of hydrothermal fluid from which the carbonates precipitated, assuming equilibrium conditions between the fluid and the precipitated mineral prevailed. Three of the samples for which isotopic measurements were made were hand-picked from calcite crystals adjacent to crystals from which fluid inclusion measurements were made. For the other three, isotopic measurements were made from bulk samples (Table 1). However, there may be some error introduced for these latter samples because some of the carbonate concretions at MV are isotopically zoned (Al-Aasm and Blaise, 1991; Goodfellow et al., 1994). The MV vent fluids from Sites 858 and 856 have estimated $\mathrm{pH}$ values of 5.5 and 5.1 , respectively (Butterfield et al., this volume), which limits the dominant carbon species in solution to $\mathrm{CO}_{2}$ and $\mathrm{H}_{2} \mathrm{CO}_{3}$. Carbon isotope fractionations in systems containing $\mathrm{H}_{2} \mathrm{CO}_{3}$ are unknown, but at 


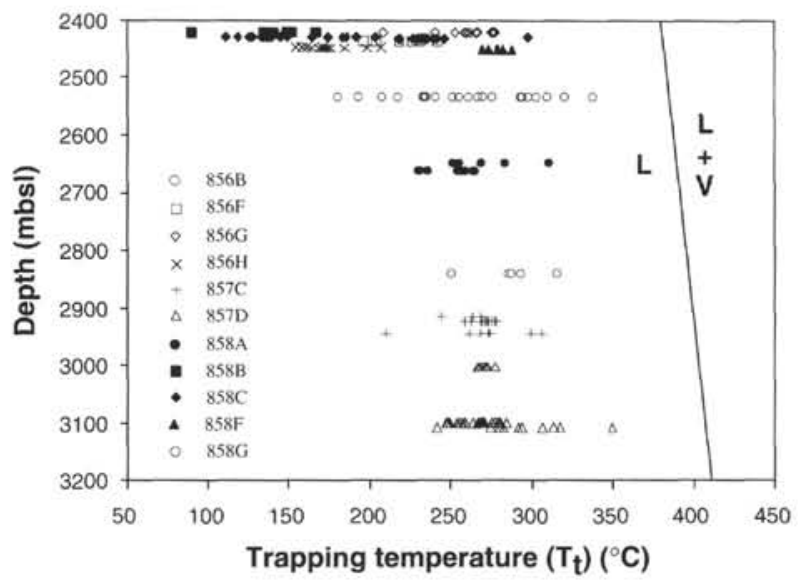

Figure 8. Fluid inclusion trapping temperature vs. sample depth (by drill hole). Liquid (L)-vapor (V) coexistence curve shown (from Bischoff and Pitzer, 1985 ) is for a fluid of seawater salinity.

temperatures above $100^{\circ} \mathrm{C}, \mathrm{H}_{2} \mathrm{CO}_{3}$ in solution may be isotopically approximated by $\mathrm{CO}_{2}$ gas (Ohmoto, 1972). Therefore, calcite- $\mathrm{CO}_{2}$ and dolomite- $\mathrm{CO}_{2}$ fractionation can be used to investigate the initial carbon isotopic composition of the hydrothermal fluid.

The $\delta^{13} \mathrm{C}$ composition of the fluid was determined from calcite data using the expression of Bottinga (1969):

$$
\begin{gathered}
1000 \ln \alpha_{\text {calcite- }-\mathrm{CO}_{2}}=-8.914 / \mathrm{T}^{3} \times 10^{8}+8.557 / \mathrm{T}^{2} \times \\
10^{6}-18.11 / \mathrm{T} \times 10^{3}+8.27 .
\end{gathered}
$$

The $\delta^{13} \mathrm{C}$ composition of the fluid was determined from dolomite data using the expression given in Ohmoto and Rye (1979), which was calculated using the equilibrium isotopic fractionation factor for dolomite and carbon dioxide of Sheppard and Schwarcz (1970):

$$
\begin{gathered}
1000 \ln \alpha_{\text {dolomite- } \mathrm{CO}_{2}}=-8.914 / \mathrm{T}^{3} \times 10^{8}+8.737 / \mathrm{T}^{2} \times \\
10^{6}-18.11 / \mathrm{T} \times 10^{3}+8.44 .
\end{gathered}
$$

Calculated carbon isotope compositions for the fluids range between $-35.4 \%$ and $-7.0 \%$ (Table 3 ) and are similar to measured vent fluid $\delta^{13} \mathrm{C}$ compositions, which range between $-32.98 \%$ and $-10.64 \%$ (Taylor, 1990). These light compositions have been explained by Goodfellow et al. (1994) to result from the oxidation of hydrothermally derived methane by sulfate-reducing bacteria, as proposed by Reeburgh (1980), where methane is oxidized either thermogenically within the sedimentary pile or biogenically at the seafloor.

Oxygen isotope compositions of fluid from which calcite was precipitated were calculated using the fractionation factor for the calcite-water system determined experimentally by O'Neil et al. (1969) combined with the $\mathrm{CO}_{2}-\mathrm{H}_{2} \mathrm{O}$ fractionation factor at $25^{\circ} \mathrm{C}(\alpha=1.0412$; O'Neil et al., 1975). This results in the following expression of Friedman and O'Neil (1977):

$$
1000 \ln \alpha_{\text {calcite-water }}=2.78\left(10^{6} \mathrm{~T}^{-2}\right)-2.89,
$$

where $\mathrm{T}$ is in Kelvin. Oxygen isotope compositions of fluid from which dolomite was precipitated were calculated using the experimentally determined fractionation expression for the dolomite-water system of Northrop and Clayton (1966):

$$
1000 \ln \alpha_{\text {dolomite-water }}=3.20\left(10^{6} \mathrm{~T}^{-2}\right)-1.50,
$$

where $\mathrm{T}$ is in Kelvin. Rather than using this dolomite-water fractionation curve, we could have used the curves of Land (1980, 1985). Although these alternate equations produce slightly different $\delta^{18} \mathrm{O}$ values for the fluid, the differences are insufficient to alter the conclusions reached. Descriptions of the samples used, and the estimated oxygen and carbon isotope compositions of the hydrothermal fluid, are listed in Table 3.

Sample 139-858C-3H-3, 22-24 cm, the highest temperature sample for which isotope data was obtained, gives an estimated fluid composition $\left(\delta^{18} \mathrm{O}=+0.4 \%\right)$ that is similar to fluids sampled to date from modern hydrothermal black smokers. Craig et al. (1980) reported the oxygen isotope composition of one vent fluid sample from $21^{\circ} \mathrm{N}$, EPR at $+1.6 \%$; a revised value for the fluid was given by Bowers and Taylor $(1985 ;+2.5 \%)$. Merlivat et al. $(1987)$ report $\delta^{18} \mathrm{O}$ values from $13^{\circ} \mathrm{N}$, EPR, of $+0.39 \%$ to $+0.69 \%$. Brines from the Red Sea have $\delta^{18} \mathrm{O}$ values of $+1 \%$ to $+2 \%$ (Craig, 1969). The fluid compositions calculated for calcite from carbonate concretions (Samples $858 \mathrm{C}-3 \mathrm{H}-1,145-150 \mathrm{~cm}$, and $858 \mathrm{C}-3 \mathrm{H}-2,10-15 \mathrm{~cm})$ are significantly enriched in ${ }^{18} \mathrm{O}(+11.7 \%$ and $+9.3 \%)$, in comparison to modern high-temperature hydrothermal fluids. One sample of calcite from calcite-pyrite veins which cross-cut sediment gives a fluid composition of $+18.6 \%$. Two samples of dolomite, which fills interstices in sulfides, have fluid compositions of $+3.2 \%$ and $+4.2 \%$, which are less enriched than the concretions but are still more enriched than modern hydrothermal vent fluids.

Several possible mechanisms can explain high- ${ }^{18} \mathrm{O}$ fluids: (1) mixing with juvenile, magmatic fluids; (2) high-temperature interaction of seawater with rocks at low w/r (Ohmoto and Rye, 1974; PisuthaArnond and Ohmoto, 1983; Bowers and Taylor, 1985); (3) exchange with ${ }^{18} \mathrm{O}$-enriched volcanic and/or sedimentary rocks (Barriga and Kerrich, 1984); (4) enrichment by ultra-filtration. In ultrafiltration, water circulating through clay or shale undergoes isotopic fractionation, and the residual water is enriched in ${ }^{18} \mathrm{O}$ over the starting water and ultrafiltrate (Coplen and Hanshaw, 1973). However, this process only enriches the residual fluid in the heavy isotope by less than $1 \%$ and cannot, therefore, explain the heavy values obtained in this study. Although interaction with basaltic rocks likely affected the oxygen isotope composition of the fluids significantly, the fluids are even more ${ }^{18} \mathrm{O}$-enriched than waters in equilibrium with normal mafic magmas $(6 \% \pm 0.5 \%)$ and juvenile waters $(6 \% \pm 1 \%)$ (Taylor, 1979) and, therefore, must have also undergone isotopic exchange with sediments.

Thus, the most plausible explanation for the ${ }^{18} \mathrm{O}$-enriched nature of the MV hydrothermal fluids is that they have interacted with sediments rich in authigenic silicate phases that are enriched in ${ }^{18} \mathrm{O}$ in the subsurface. Most clay minerals have $\delta^{18} \mathrm{O}$ values typically between $+15 \%$ and $+30 \%$ (e.g., Hoefs, 1980; Savin and Epstein, 1970a, 1970b; Lawrence and Taylor, 1971, 1972). Oxygen isotope analyses of two samples of unaltered hemipelagic sediment from MV give $\delta^{18} \mathrm{O}$ compositions of $+10.9 \%$ and $+11.7 \%$ (Goodfellow et al., 1994) and fall within the range of $+9 \%$ to $+13 \%$ for ocean sediments on a carbonatefree basis (Savin and Epstein, 1970b). Formation waters are typically ${ }^{18} \mathrm{O}$-enriched from exchange with subsurface sediments (Clayton et al., 1966; Hitchon and Friedman, 1969; Kharaka et al., 1973).

Goodfellow et al. (in press) used the oxygen isotope compositions of carbonate concretions to calculate precipitation temperatures in the range of $60^{\circ}$ to $100^{\circ} \mathrm{C}$ by assuming $\delta^{18} \mathrm{O}$ values of $0 \%$ for the fluid. Baker et al. (this volume) used the same technique to calculate maximum temperatures for carbonates in ODP cores from MV in the range of $165^{\circ}$ to $222^{\circ} \mathrm{C}$. However, our data are considerably more complex and show variable enrichments of the MV hydrothermal fluids in ${ }^{18} \mathrm{O}$ which are likely a result of interaction with subsurface sediments at variable $\mathrm{w} / \mathrm{r}$. Thus, temperatures for carbonate precipitation calculated assuming the fluid has a $\delta^{18} \mathrm{O}$ composition of $0 \%$ may be too low.

\section{CONCLUSIONS}

Fluid inclusion studies of hydrothermal precipitates in Hole 858C in MV indicate carbonate concretions in the outer low-temperature alteration zone formed at temperatures between $112^{\circ}$ and $192^{\circ} \mathrm{C}$. Hydrothermal minerals were precipitated near the core of the upflow 
Table 3. Carbon and oxygen isotope compositions of calcite and dolomite, and calculated carbon and oxygen isotope compositions of hydrothermal fluid in equilibrium with these minerals. See text for details of calculations.

\begin{tabular}{|c|c|c|c|c|c|c|}
\hline Sample Number & Sample Type & $\begin{array}{l}\text { Mean } T_{t} \\
\left( \pm 1 \sigma^{\circ} \mathrm{C}\right)\end{array}$ & $\begin{array}{c}\delta^{18} \mathrm{OSMOW}_{\text {SMO }} \\
\text { carbonate }(\% 0)\end{array}$ & $\begin{array}{l}\delta^{18} \mathrm{OSMOW}_{\text {SMOW }} \\
\text { fluid }(\% \circ)^{*}\end{array}$ & $\begin{array}{c}\delta^{13} \mathrm{C}_{\text {PDB }} \\
\text { carbonate }(\%)\end{array}$ & $\begin{array}{l}\delta^{13} \mathrm{CPDB}_{\text {PD }} \\
\text { fluid }(\% \circ)^{8}\end{array}$ \\
\hline $856 \mathrm{~F}-2 \mathrm{X}-\mathrm{CC}, 23-25 \mathrm{~cm}$ & $\begin{array}{l}\text { bulk dolomite matrix with } \\
\text { sulfide clasts \& indurated } \\
\text { sediment }\end{array}$ & $220 \pm 17(n=6)$ & $+14.8^{\#}$ & +3.2 & $-15.5^{\#}$ & -15.7 \\
\hline $856 \mathrm{H}-3 \mathrm{R}-2,16-18 \mathrm{~cm}$ & $\begin{array}{l}\text { bulk dolomite matrix } \\
\text { interstitial to sulfides }\end{array}$ & $170 \pm 21(n=5)$ & $+18.9^{\#}$ & +4.2 & $-5.2^{\#}$ & -7.0 \\
\hline $858 \mathrm{C}-3 \mathrm{H}-1,78-81 \mathrm{~cm}$ & $\begin{array}{l}\text { bulk calcite from calcite- } \\
\text { pyrite veins cutting } \\
\text { sediment }\end{array}$ & $195 \pm 13(n=2)$ & $+28.4^{\#}$ & +18.6 & $-33.9^{\#}$ & -33.9 \\
\hline $858 \mathrm{C}-3 \mathrm{H}-1,145-150 \mathrm{~cm}$ & $\begin{array}{l}\text { hand-picked calcite crystals } \\
\text { from calcite concretion }\end{array}$ & $133 \pm 10(n=10)$ & +23.2 & +9.3 & -33.1 & -35.4 \\
\hline $858 \mathrm{C}-3 \mathrm{H}-2,10-15 \mathrm{~cm}$ & $\begin{array}{l}\text { hand-picked calcite crystals } \\
\text { from calcite concretion }\end{array}$ & $158 \pm 25(n=8)$ & +25.3 & +13.2 & -29.6 & -30.7 \\
\hline $858 \mathrm{C}-3 \mathrm{H}-3,22-24 \mathrm{~cm}$ & $\begin{array}{l}\text { hand-picked calcite crystals } \\
\text { in hydrothermally altered, } \\
\text { calcite \& sulfide-bearing } \\
\text { sediment }\end{array}$ & $233 \pm 7(n=17)$ & +8.3 & +0.4 & -21.0 & -20.0 \\
\hline \multicolumn{7}{|c|}{$\begin{array}{l}\text { *oxygen isotope composition of fluid calculated using the mean fluid inclusion trapping temperature and either the calcite, the calcite-water } \\
\text { equation of Friedman and O'Neil (1977), or the dolomite-water equation of Northrop and Clayton (1966), all of which assume equilibrium } \\
\text { fractionation between the mineral and fluid. }\end{array}$} \\
\hline \multicolumn{7}{|c|}{$\begin{array}{l}\text { \& carbon isotope composition of fluid calculated using the mean fluid inclusion trapping temperature and either the calcite- } \mathrm{CO}_{2} \text { equation of } \\
\text { Bottinga (1969) or the empirical fractionation factors between dolomite and calcite of Sheppard and Schwarcz (1970) which assume } \\
\text { equilibrium fractionation between the mineral and fluid. }\end{array}$} \\
\hline
\end{tabular}

zone at higher temperatures, between about $200^{\circ} \mathrm{C}$ and $350^{\circ} \mathrm{C}$. These temperatures are similar to those for presently venting hydrothermal fluids. $\mathrm{T}_{\mathrm{t}}$ and salinities for Site 857 , and for high-temperature inclusions from Site 858 are similar and are consistent with a common origin for the fluids at these two sites. $\mathrm{T}_{\mathrm{t}}$ for sphalerite at Site 856 are similar to temperatures from Sites 857 and 858 ; however, salinities from Site 856 are slightly higher. There is a general increase in minimum $T_{t}$ with increasing depth due to conductive heating from cooling sills and/or intrusives and mixing with down-drawn cold seawater which cools fluids in the upper part of the upflow zone. Fluid inclusion microthermometric data indicate that $\mathrm{Ca}, \mathrm{Na}$, and $\mathrm{Cl}$ are the dominant ionic species, and the hydrothermal fluids are modified seawater. Salinities for most inclusion fluids range between 2.5 and 7.0 eq. $w t \% \mathrm{NaCl}$, and most are similar to ambient bottom water $(\approx 3.2$ wt $\%$ ). Estimated carbon isotope compositions of the evolved hydrothermal fluids on the margin of fluid upflow $\left(\delta^{13} \mathrm{C}=-7.0 \%\right.$ to $\left.-35.4 \%\right)$ are similar to presently venting hydrothermal fluids. Most estimated oxygen isotope compositions of these fluids are considerably enriched in ${ }^{18} \mathrm{O}(+3.2 \%$ to $+18.6 \%)$ compared to seawater and indicate significant isotopic exchange with sediments. Furthermore, the variability in calculated carbon and oxygen isotope compositions of hydrothermal fluids indicate complex spatial and possibly temporal variations in processes that fractionate these isotopes, and likely result from fluctuating water/rock ratios.

\section{ACKNOWLEDGMENTS}

We thank Jim Franklin for providing samples of veins within mafic sills for study and John Lydon for discussion. This work was performed while J.M. Peter held a Natural Sciences and Engineering Research Council of Canada Visiting Fellowship. We thank David A. Vanko and Craig H.B. Leitch for very thorough reviews. The incisive criticisms and comments of David Vanko were of particular help and greatly improved this paper. We also acknowledge the editorial comments of N. McQuistion. This is Geological Survey of Canada contribution no. 47392 .

\section{REFERENCES ${ }^{*}$}

Barriga, F.J.A.S., and Kerrich, R., 1984. Extreme ${ }^{18} \mathrm{O}$-enriched volcanics and ${ }^{18} \mathrm{O}$-evolved marine water, Alujustrel, Iberian pyrite belt: transition from high to low Rayleigh number convective regimes. Geochim. Cosmochim. Acta, 48:1021-1031.

Bischoff, J.L., and Pitzer, K.S., 1985. Phase relations and adiabats in boiling seafloor geothermal systems. Earth Planet. Sci. Lett., 75:327-338.

Bodnar, R.J., 1993. Revised equation and table for determining the freezing point depression of $\mathrm{H}_{2} \mathrm{O}-\mathrm{NaCl}$ solutions. Geochim. Cosmochim. Acta, 57:683-684.

Bodnar, R.J., and Bethke, P.M., 1984. Systematics of stretching of fluid inclusions, I: Fluorite and sphalerite at 1 atmosphere confining pressure. Econ. Geol., 79:141-161.

Bodnar, R.J., Reynolds, T.J., and Kuehn, C.A., 1985. Fluid inclusion systematics in epithermal systems. Rev. Econ. Geol., 2:73-98.

Borisenko, A.S., 1977. Study of the salt composition of solutions in gas-liquid inclusions in minerals by the cryometric method. Sov. Geol. Geophys. Eng. Transl., 18:11-19.

Bottinga, Y., 1969. Calculated fractionation factors for carbon and hydrogen isotopic exchange in the system calcite-carbon dioxide-graphite, methanehydrogen-water vapor. Geochim. Cosmochim. Acta, 33:49-64.

Bowers, T.S., and Taylor, H.P., Jr., 1985. An integrated chemical and stable isotope model of the origin of midocean ridge hot spring systems. J. Geophys. Res., 90:12583-12606.

Clayton, R.N., Friedman, I., Graf, D.L., Mayeda, T.K., Meents, W.F., and Shimp, N.F., 1966. The origin of saline formation waters, I. Isotopic composition. J. Geophys. Res., 71:3869-3882.

Coplen, T.B., and Hanshaw, B.D., 1973. Ultrafiltration by a compacted clay membrane, I. Oxygen and hydrogenisotopic fractionation. Geochim. Cosmochim. Acta, 37:2295-2310.

Craig, H., 1969. Geochemistry and origin of the Red Sea brines. In Degens, E.T., and Ross, D.A. (Eds.), Hot Brines and Recent Heavy Metal Deposits in the Red Sea: New York (Springer-Verlag), 208-242.

\footnotetext{
-Abbreviations for names of organizations and publications in ODP reference lists follow the style given in Chemical Abstracts Service Source Index (published by American Chemical Society).
} 
Craig, H., Welhan, J.A., Kim, K., Poreda, R., and Lupton, J.E., 1980. Geochemical studies of the $21^{\circ} \mathrm{N}$ EPR hydrothermal fluids. Eos, 61:992.

Crawford, M.L., 1981. Phase equilibria in aqueous fluid inclusions. Fluid Inclusions: Applications to Petrology. Mineral. Assoc. Can., 75-100.

Crawford, M.L., Filer, J., and Wood, C., 1979. Saline fluid inclusions associated with retrograde metamorphism. Bull. Mineral., 102:562-568.

Davis, D.W., Lowenstein, T.K., and Spencer, R.J., 1990. Melting behavior of fluid inclusions in laboratory-grown halite crystals in the systems $\mathrm{NaCl}$ $\mathrm{H}_{2} \mathrm{O}, \mathrm{NaCl}-\mathrm{H}_{2} \mathrm{O}, \mathrm{NaCl}-\mathrm{MgCl}_{2}-\mathrm{H}_{2} \mathrm{O}$, and $\mathrm{NaCl}-\mathrm{CaCl}_{2}-\mathrm{H}_{2} \mathrm{O}$, Geochim. Cosmochim. Acta, 54:91-601.

Davis, E.E., Goodfellow, W.D., Bornhold, B.D., Adshead, J., Blaise, B., Villinger, H., and Le Cheminant, G.M., 1987. Massive sulfides in a sedimented rift valley, northern Juan de Fuca Ridge. Earth Planet. Sci. Lett., 82:49-61.

Davis, E.E., Mottl, M.J., Fisher, A.T., et al., 1992.Proc. ODP, Init. Repts., 139: College Station, TX (Ocean Drilling Program).

Davis, E.E., and Sawyer, B., 1987. Marine geophysical maps of western Canada. Geol. Surv. Can. Bathymetric Map 6-1987.

Davis, E.E., and Villinger, H., 1992. Tectonic and thermal structure of the Middle Valley sedimented rift, northern Juan de Fuca Ridge. In Davis, E.E., Mottl, M.J., Fisher, A.T., et al., Proc. ODP, Init. Repts., 139: College Station, TX (Ocean Drilling Program), 9-41.

Franklin, J.M., Goodfellow, W.D., Ames, D.E., Lydon, J.W., Jonasson, I.R., and Davis, E.E., 1991. Middle Valley, a major centre of hydrothermal activity in a sedimented ridge crest, northern Juan de Fuca Ridge. Progr. with Abstr., Geol. Surv. Can., Curr. Activ. Forum, Ottawa, 20.

Franklin, J.M., and Leg 139 Scientific Party, 1992. Formation of massive sulphide deposits in Middle Valley, northern Juan de Fuca Ridge. Geol. Surv. Can. Minerals Colloq., Ottawa, Abstr. with Progr., 20.

Friedman, I., and O'Neil, J., 1977. Compilation of stable isotope fractionation factors of geochemical interest. In Fleischer, M. (Ed.), Data of Geochemistry (6th Ed.). Geol. Surv. Prof. Pap. U.S., 440-KK:1-12.

Gerard, R., 1966. Salinity in the ocean. In The Encyclopedia of Oceanography: Toronto (Van Nostrand Reinhold).

Gieskes, J.M., and Lawrence, J.R., 1981. Alteration of volcanic matter in deepsea sediments: evidence from the chemical composition of interstitial waters from deep-sea drilling cores. Geochim. Cosmochim. Acta, 45:1687-1703.

Goodfellow, W.D., and Blaise, B., 1988. Sulfide formation and hydrothermal alteration of hemipelagic sediment in Middle Valley, northern Juan de Fuca Ridge. Can. Mineral., 26:675-696.

Goodfellow, W.D., and Franklin, J.M., in press. Geology, mineralogy and geochemistry of massive sulfides in shallow cores, Middle Valley, Northern Juan de Fuca Ridge. Econ. Geol.

Goodfellow, W.D., Grapes, K., Cameron, B., and Franklin, J.M., 1994. Hydrothermal alteration associated with massive sulfide deposits, Middle Valley, Northern Juan de Fuca Ridge. Can. Mineral., 31:1025-1060.

Hedenquist, J.W., and Henley, R.W., 1985. The importance of $\mathrm{CO}_{2}$ on freezing point measurements of fluid inclusions: evidence from active geothermal systems and implications for epithermal ore deposition. Econ. Geol. 80:1379-1406.

Hitchon, B., and Friedman, I., 1969. Geochemistry and origin of formation waters in the western Canada sedimentary basin. I. Stable isotopes of hydrogen and oxygen. Geochim. Cosmochim. Acta, 33:1321-1349.

Hoefs, J., 1980. Stable Isotope Geochemistry (2nd ed.): New York (SpringerVerlag).

Holland, R.A.G., Bray, C.J., and Spooner, E.T.C., 1978. A method for preparing thin sections suitable for microthermometric examination of fluid inclusions. Mineral. Mag., 42:407-408.

Kharaka, Y.K., Berry, F.A.F., and Friedman, I., 1973. Isotopic composition of oil-field brines from Kettleman North Dome oil field, California, and their geologic implications. Geochim. Cosmochim. Acta, 37:1899-1908.

Land, L.S., 1980. The isotopic and trace element geochemistry of dolomite: the state of the art. In Zenger, D.H., Dunham, J.B., and Ethington. R.L. (Eds.), Concepts and Models of Dolomitization. Soc. Econ. Paleontol. Mineral. Pomona Coll., 87-110.

- 1985. The origin of massive dolomite. J. Geol. Educ., 33:112-125.

Lawrence, J.R., and Gieskes, J.M., 1981. Constraints on water transport and alteration in the oceanic crust from the isotopic composition of pore water. J. Geophys. Res., 86:7924-7934.

Lawrence, J.R., Gieskes, J.M., and Broecker, W.S., 1975. Oxygen isotope and cation composition of DSDP pore water and the alteration of layer Il basalts. Earth Planet. Sci. Lett., 27:1-10.

Lawrence, J.R., and Taylor, H.P., 1972. Hydrogen and Oxygen isotope systematics in weathering profiles. Geochim. Cosmochim. Acta, 36:1377-1393.
Lawrence, J.R., and Taylor, H.P., Jr., 1971. Deuterium and oxygen-18 correlation: clay minerals and hydroxides in Quaternary soils compared to meteoric waters. Geochim. Cosmochim. Acta, 35:993-1003.

Leitch, C.H.B., 1991. Preliminary studies of fluid inclusions in barite from the Middle Valley sulphide mounds, northern Juan de Fuca Ridge. Geol. Surv. Can. Curr. Res., Part A., 27-30.

Liou, J.G., 1971. Pressure-temperature stabilities of laumontite, wairakite, lawsonite, and related minerals in the system $\mathrm{CaAl}_{2} \mathrm{Si}_{2} \mathrm{O}_{8}-\mathrm{H}_{2} \mathrm{O}$. J. Petrol., $12: 379-411$

Lydon, J.W., Goodfellow, W.D., and Franklin, J.M., 1990. Chemistry of sediment pore waters around active hydrothermal vents, Middle Valley. Am. Geophys. Union, Annual Meeting Progr. Abstr., 71:1569.

, 1991. Spatial control and pore water compositions of active and extinct hydrothermal fields in Middle Valley. Int. Conf. on Fluids in Subduction Zones, Paris, France.

Lydon, J.W., Goodfellow, W.D., and Gregoire, D.C., 1992. Chemical composition of vent and pore fluids in an active hydrothermal discharge zone, Middle Valley. Geol. Surv. Can. Minerals Colloq., Progr. Abstr., 7.

McCrea, J.M., 1950. Isotopic chemistry of carbonates and a paleotemperature scale. J. Chem. Phys., 18:849-857.

MacDonald, A.J., and Spooner, E.T.C., 1981. Calibration of a Linkam TH600 programmable heating-cooling stage for microthermometric examination of fluid inclusions. Econ. Geol., 76:1248-1258.

Merlivat, L.. Pineau, F., and Javoy, M., 1987. Hydrothermal vent waters at $13^{\circ} \mathrm{N}$ on the East Pacific Rise: isotopic composition and gas concentration. Earth Planet. Sci. Lett., 84:100-108.

Michard, G., Albarede, F., Michard, A., Minster, J.-F., Charlou, J.-L., and Tan, N., 1984. Chemistry of solutions from $13^{\circ} \mathrm{N}$ East Pacific Rise hydrothermal site. Earth Planet. Sci. Lett., 67:297-308.

Moore, J.N., Adams, M.C., and Lemieux, M.M., 1992. The formation and distribution of $\mathrm{CO}_{2}$-enriched fluid inclusions in epithermal environments. Geochim. Cosmochim. Acta, 56:121-135.

Mottl, M.J., Holland, H.D., and Corr, R.F., 1979. Chemical exchange during hydrothermal alteration of basalt by seawater. II. Experimental results for $\mathrm{Fe}, \mathrm{Mn}$ and sulfur species. Geochim. Cosmochim. Acta, 43:869-884.

Northrop, D.A., and Clayton, R.N., 1966. Oxygen-isotope fractionations in systems containing dolomite. J. Geol., 74:174-196.

Oakes, C.S., Bodnar, R.J., and Simonson, J.M., 1990. The system NaCl-CaCl${ }_{2}^{-}$ $\mathrm{H}_{2} \mathrm{O}$, I. The ice liquidus at 1 atm total pressure. Geochim. Cosmochim. Acta, 54:603-610.

Ohmoto, H., 1972. Systematics of sulfur and carbon isotopes in hydrothermal ore deposits. Econ. Geol., 67:551-579.

Ohmoto, H., and Rye, R.O., 1974. Hydrogen and oxygen isotopic compositions of fluid inclusions in the Kuroko deposits, Japan. Econ. Geol., 69:947-953. 1979. Isotopes of sulfur and carbon. Geochemistry of Hydrothermal Ore Deposits (2nd ed.): New York (Wiley), 509-567.

O'Neil, J.R., Adami, L.H., and Epstein, S., 1975. Revised value for the ${ }^{18} \mathrm{O}$ fractionation between $\mathrm{CO}_{2}$ and $\mathrm{H}_{2} \mathrm{O}$ at $25^{\circ} \mathrm{C}$. J. Res. U.S. Geol. Surv., 3:623-624.

O'Neil, J.R., Clayton, R.N., and Mayeda, T.K., 1969. Oxygen isotope fractionation in divalent metal carbonates. J. Chem. Phys., 51:5547-5558.

Peter, J.M., and Scott, S.D., 1988. Mineralogy, composition, and fluid-inclusion microthermometry of seafloor hydrothermal deposits in the southern trough of Guaymas Basin, Gulf of California. Can. Mineral., 26:567-587.

, 1991. Hydrothermal mineralization in the Guaymas Basin, Gulf of California. AAPG Mem., 47:721-741.

Pisutha-Arnond, V., and Ohmoto, H., 1983. Thermal history, and chemical and isotopic compositions of the ore-forming fluids responsible for the Kuroko massive sulfide deposits in the Hokuroku District of Japan. Econ. Geol. Monogr., 5:523-558.

Potter, R.W., 1977. Pressure corrections for fluid-inclusion homogenization temperatures based on the volumetric properties of the system $\mathrm{NaCl}-\mathrm{H}_{2} \mathrm{O}$. J. Res. U.S. Geol. Surv, 5:603-607.

Potter, R.W., II, and Brown, D.L., 1977. The volumetric properties of aqueous sodium chloride solutions from $0^{\circ} \mathrm{C}$ to $500^{\circ} \mathrm{C}$ at pressures up to 2000 bars based on a regression of available data in the literature. U.S. Geol. Surv. Bull., 1421-C:1-35.

Reeburgh, W.S., 1980. Anaerobic methane oxidation: rate depth distribution in Skan Bay sediments. Earth Planet. Sci. Lett., 47:345-352.

Roedder, E., 1984. Fluid inclusions. Rev. Mineral., Mineral. Soc. Am., 12.

Savin, S.M., and Epstein, S., 1970a. The oxygen and hydrogen isotope geochemistry of clay minerals. Geochim. Cosmochim. Acta, 34:25-42. 1970b. The oxygen and hydrogen isotope geochemistry of ocean sediments and shales. Geochim. Cosmochim. Acta, 34:43-63. 
Seyfried, W.E., Jr., and Bischoff, J.L., 1981. Experimental seawater-basalt interaction at $300^{\circ} \mathrm{C}$ and 500 bars: chemical exchange, secondary mineral formation, and implications for the transport of heavy metals. Geochim. Cosmochim. Acta, 45:135-1.

Shepherd, T.J., 1981. Temperature-programmable, heating-freezing stage for microthermometric analysis of fluid inclusions. Econ. Geol., 76:1244-1247.

Sheppard, S.M.F., and Schwarz, H.P., 1970. Fractionation of carbon and oxygen isotopes and magnesium between metamorphic calcite and dolomite. Contrib. Mineral. Petrol., 26:161-198.

Shinohara, H., Iiyama, J.T., and Matsuo, S., 1984. Geochemistry-behavior of chlorine in the system granitic magma-hydrothermal solution. C.R. Acad. Sci. Ser. 2, 298:741-743. (in French)

1989. Partition of chlorine compounds between silicate melt and hydrothermal solutions, I. Partition of $\mathrm{NaCl}-\mathrm{KCl}$. Geochim. Cosmochim. Acta, 53:2617-2630.

Simoneit, B.R.T., Goodfellow, W.D., and Franklin, J.M., 1992. Hydrothermal petroleum at the seafloor and organic matter alteration in sediments of Middle Valley, northern Juan de Fuca Ridge. Appl. Geochem., 7:257-264.

Sterner, S.M., and Bodnar, R.J., 1989. Synthetic fluid inclusions, VII. Reequilibration of fluid inclusions in quartz during laboratory-simulated metamorphic burial and uplift. J. Metamorph. Geol., 7:243-260.

Taylor, B.E., 1990. Carbon dioxide and methane in hydrothermal vent fluids from Middle Valley, a sediment-covered ridge segment. Eos, 71:1569.

Taylor, H.P., Jr., 1979. Oxygen and hydrogen isotope relationships in hydrothermal mineral deposits. In Geochemistry of Hydrothermal Ore Deposits (2nd ed.): New York (Wiley), 236-277.

Vanko, D.A., 1988. Temperature, pressure, and composition of hydrothermal fluids with their bearing on the magnitude of tectonic uplift at mid-ocean ridges, inferred from fluid inclusions in oceanic layer 3 rocks. J. Geophys. Res., 93:4595-4611.

Vanko, D.A., Bodnar, R.J., and Sterner, S.M., 1988. Synthetic fluid inclusions, VIII. Vapour saturated halite solubility in part of the system $\mathrm{NaCl}-\mathrm{CaCl}_{2}$ $\mathrm{H}_{2} \mathrm{O}$, with application to fluid inclusions from oceanic hydrothermal systems. Geochim. Cosmochim. Acta, 52:2451-2456.

Vanko, D.A., Griffith, J.D., and Erickson, C.L., 1992. Calcium-rich brines and other hydrothermal fluids in fluid inclusions from plutonic rocks, Oceanographer Transform, Mid-Atlantic Ridge. Geochim. Cosmochim. Acta, 56:35-47.

Von Damm, K.L., 1990. Seafloor hydrothermal activity: black smoker chemistry and chimneys. Annu. Rev. Earth Planet. Sci., 18:173-204.

Von Damm, K.L., and Bischoff, J.L., 1987. Chemistry of hydrothermal solutions from the southern Juan de Fuca Ridge. J. Geophys. Res., 92:1133411346.

Von Damm, K.L., Edmond, J.M., Measures, C.I., and Grant, B., 1985. Chemistry of submarine hydrothermal solutions at Guaymas Basin, Gulf of California. Geochim. Cosmochim. Acta, 49:2221-2237.

Yanatieva, O.K., 1946. Polythermal solubilities in the system $\mathrm{CaCl}_{2}-\mathrm{MgCl}_{2}-$ $\mathrm{H}_{2} \mathrm{O}$ and $\mathrm{CaCl}_{2}-\mathrm{NaCl}-\mathrm{H}_{2} \mathrm{O}$. Zh. Priklad. Khim., 19:709-722.

Date of initial receipt: 26 February 1993

Date of acceptance: 23 August 1993

Ms 139SR-233 

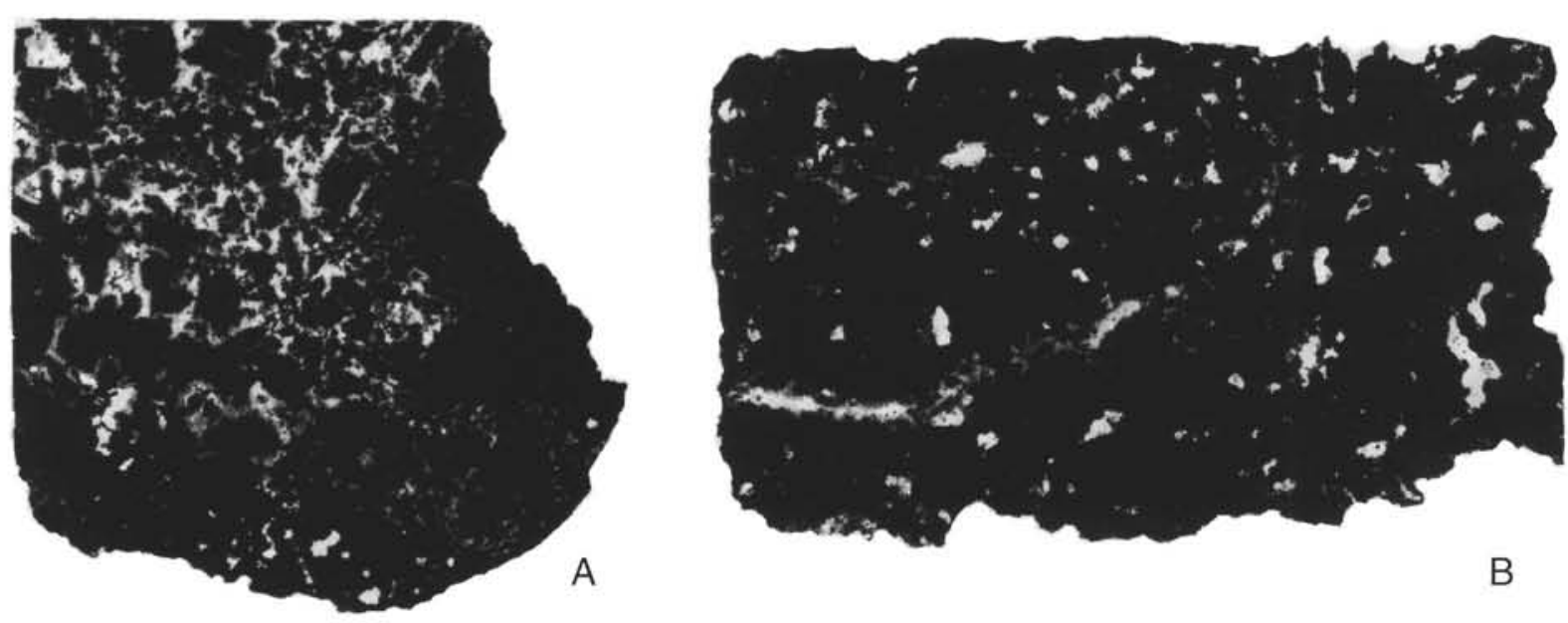

A

B
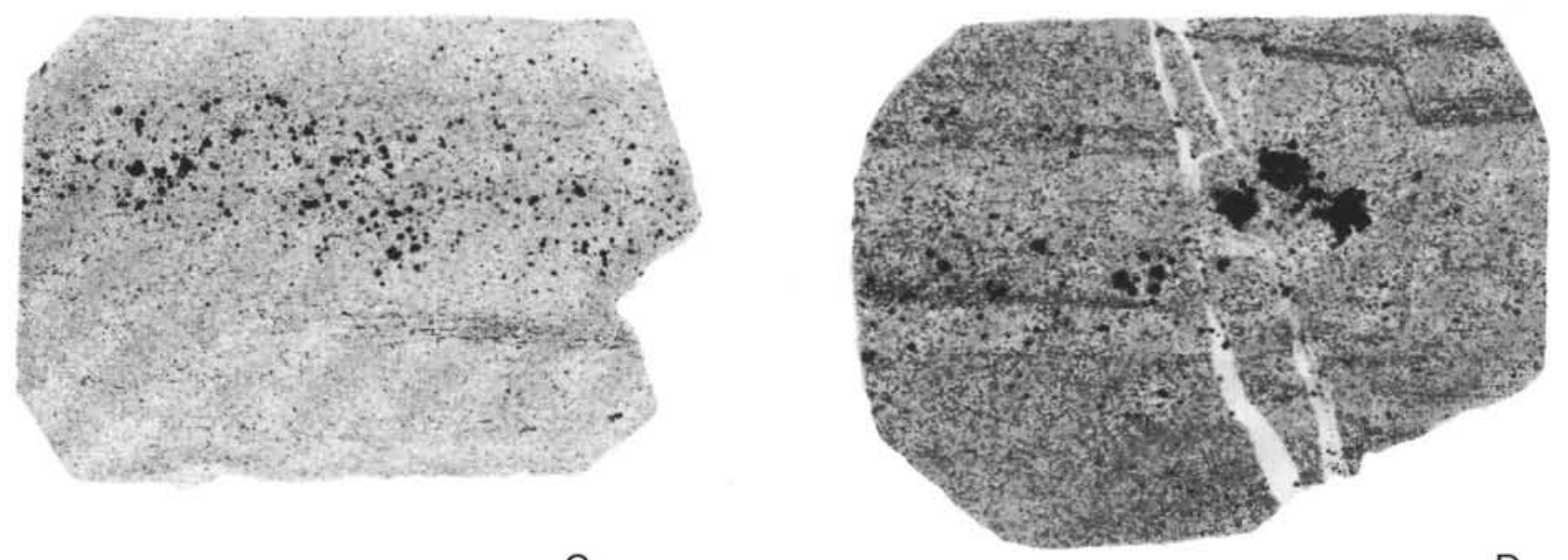

C

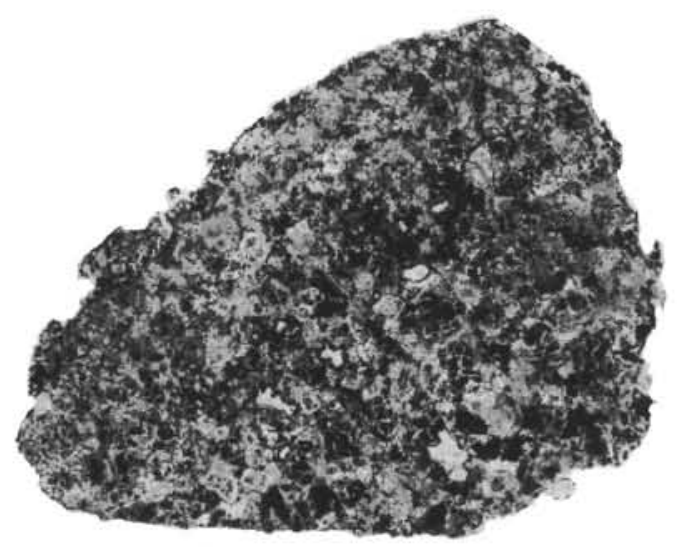

$\mathrm{E}$

$\mathrm{F}$

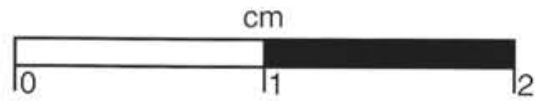

Plate 1. Transmitted light photographs of fluid inclusion sections of representative sample types. A. Sulfide clasts (black) with interstitial dolomite matrix (white), Sample 856F-2X-CC, $23-25 \mathrm{~cm}$. B. Medium- to coarse-grained sulfide (pyrite-pyrrhotite-magnetite) (black) with interstitial carbonate matrix and cross-cutting calcite veinlet (both white), Sample $856 \mathrm{H}-3 \mathrm{R}-2,135-138 \mathrm{~cm}$. C. Indistinctly, thinly laminated fine-grained sediment (white to gray) with fine-grained, disseminated pyrite restricted to a zone, Sample 857D-17R-1, 34-36 cm. D. Finely laminated fine-grained sediment (white to gray) with fine-grained disseminated pyrite (black) and cross-cutting wairakite veinlet (white) which offsets bedding, Sample 857D-17R-2, 53-55 cm. E. Mafic sill (gray to black) with cross-cutting quartz-wairakite-epidote veinlet (white), Sample 857C-60R-2, 28-30 cm. F. Coarse-grained carbonate concretion (white to gray) with interstitial clay-rich sediment (black), Sample $858 \mathrm{C}-3 \mathrm{H}-2,124-126 \mathrm{~cm}$. 

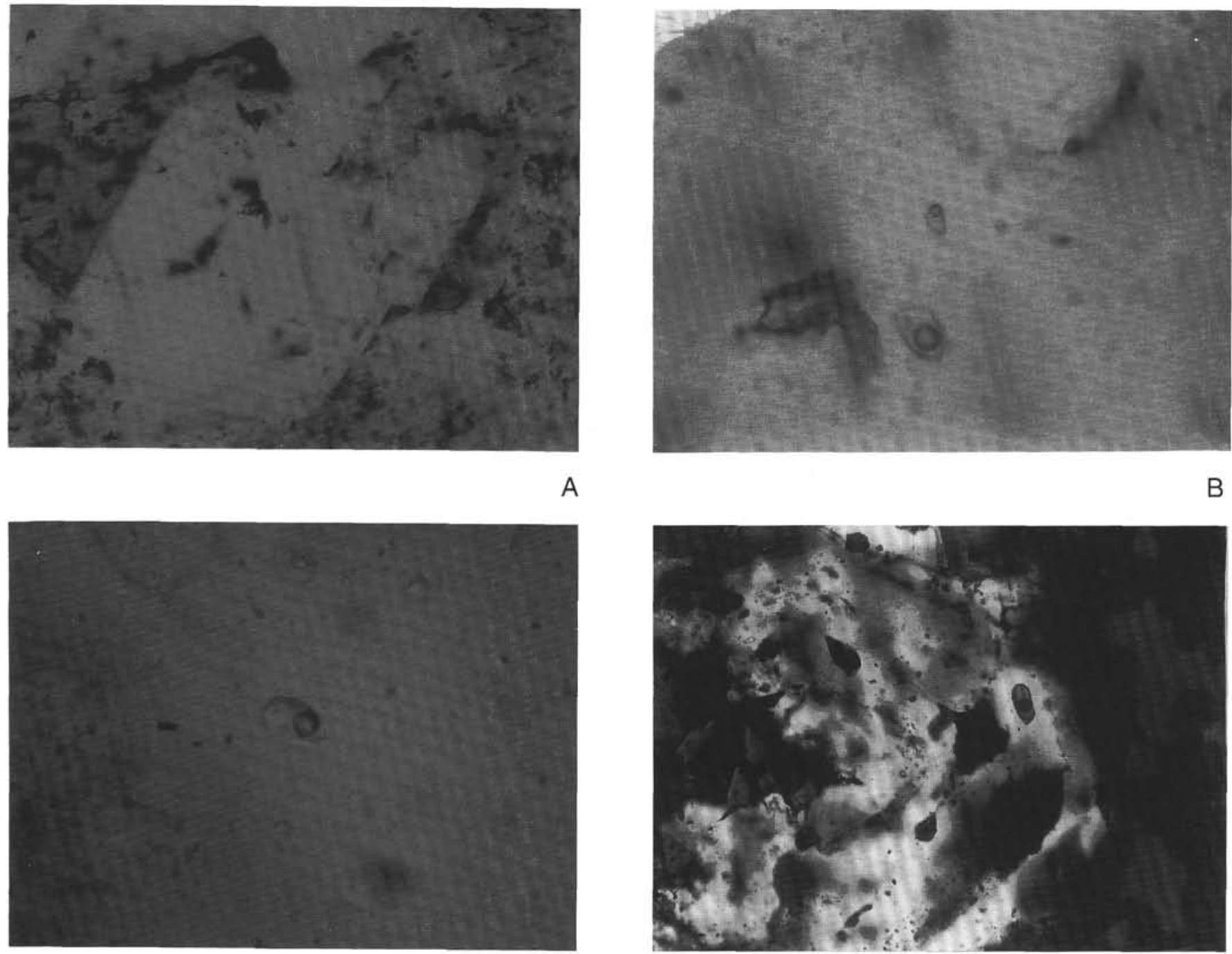

C
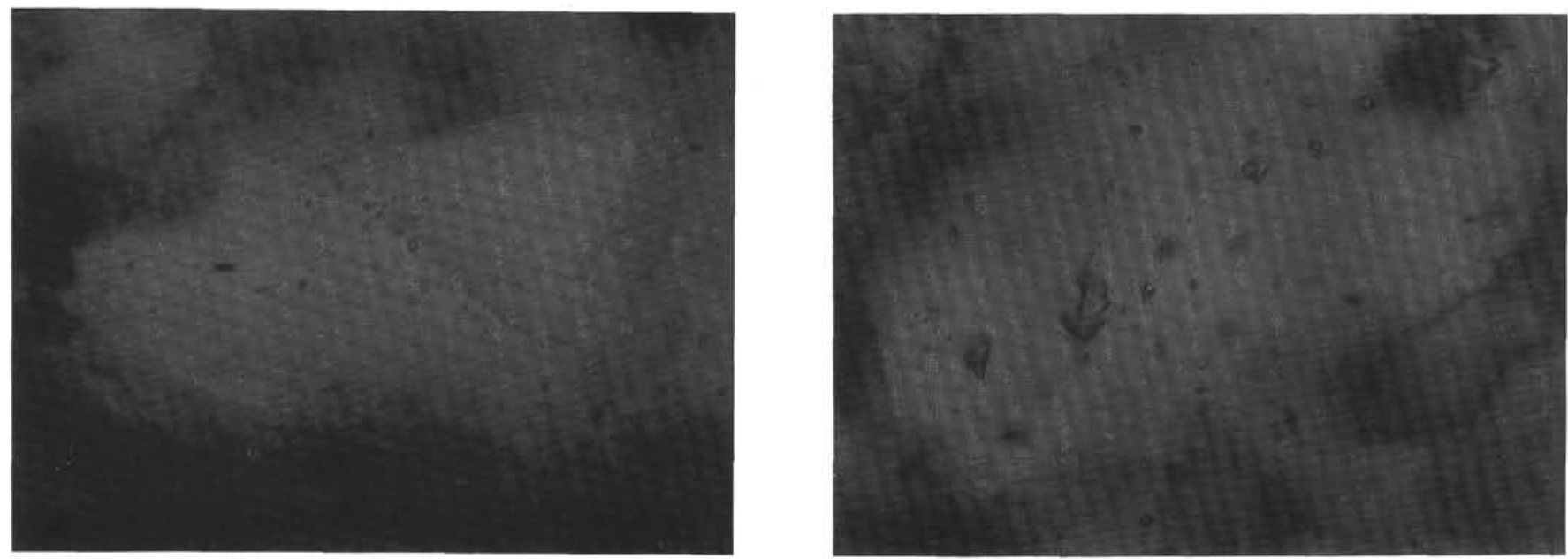

E

Plate 2. Transmitted light photomicrographs of fluid inclusions. A. Euhedral quartz crystal with several isolated primary two-phase (L,V) inclusions. Largest inclusion is $30 \mu \mathrm{m}$. Sample 858G-16R-1,77-79 cm. B. Close-up of two primary inclusions shown in (A), Sample 858G-16R-1, 77-79 cm. C. Primary two-phase $(\mathrm{L}, \mathrm{V}) 35-\mu \mathrm{m}$ inclusion in quartz, Sample $858 \mathrm{~A}-29 \mathrm{X}-1,30-32 \mathrm{~cm}$. D. 15 - $\mu \mathrm{m}$-long primary two-phase $(\mathrm{L}, \mathrm{V})$ inclusion in low-iron translucent sphalerite in massive sulfide, Sample 856G-7R-4, 4-6 cm. E. Planar array of 1- to 5- $\mu$ m predominantly two-phase $(\mathrm{L}, \mathrm{V})$ secondary inclusions along a healed microfracture in anhedral quartz, Sample 857D-17R-1, 34-36 cm. F. 2- to 10- $\mu \mathrm{m}$ two-phase (L,V) and one-phase (V) secondary inclusions along several healed microfractures in anhedral quartz, Sample 858A-29X-1, 30-32 cm. 

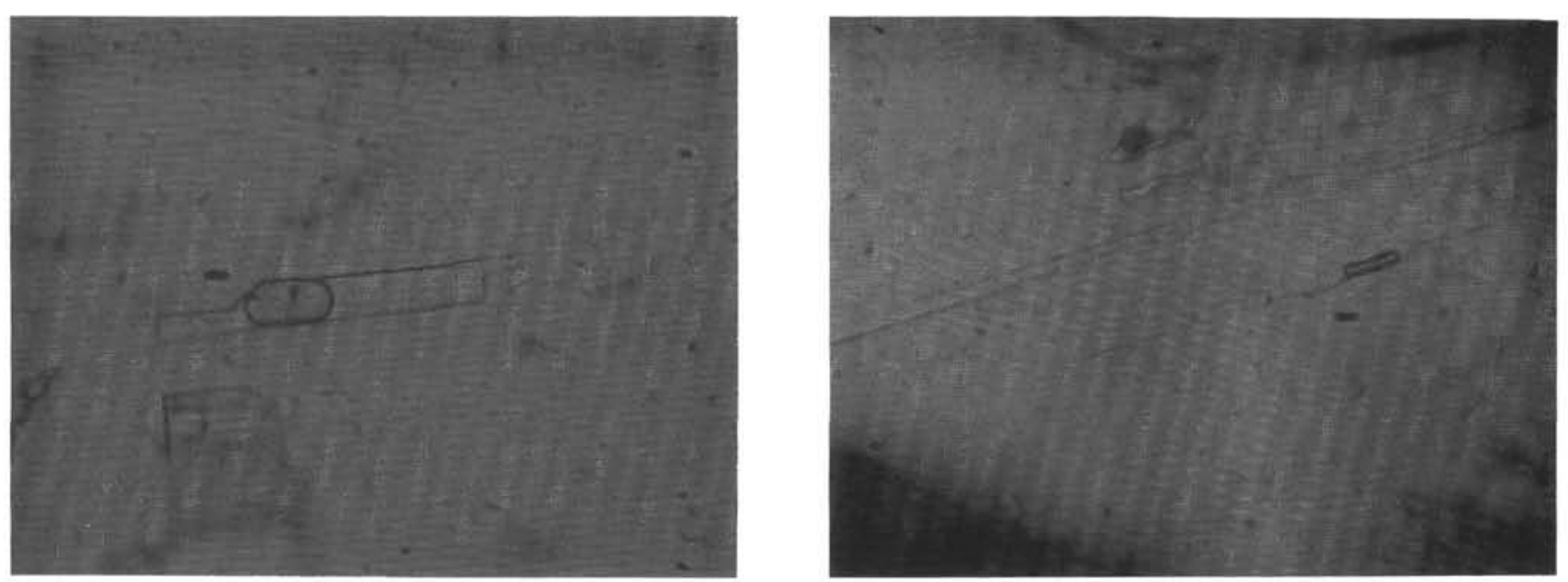

A
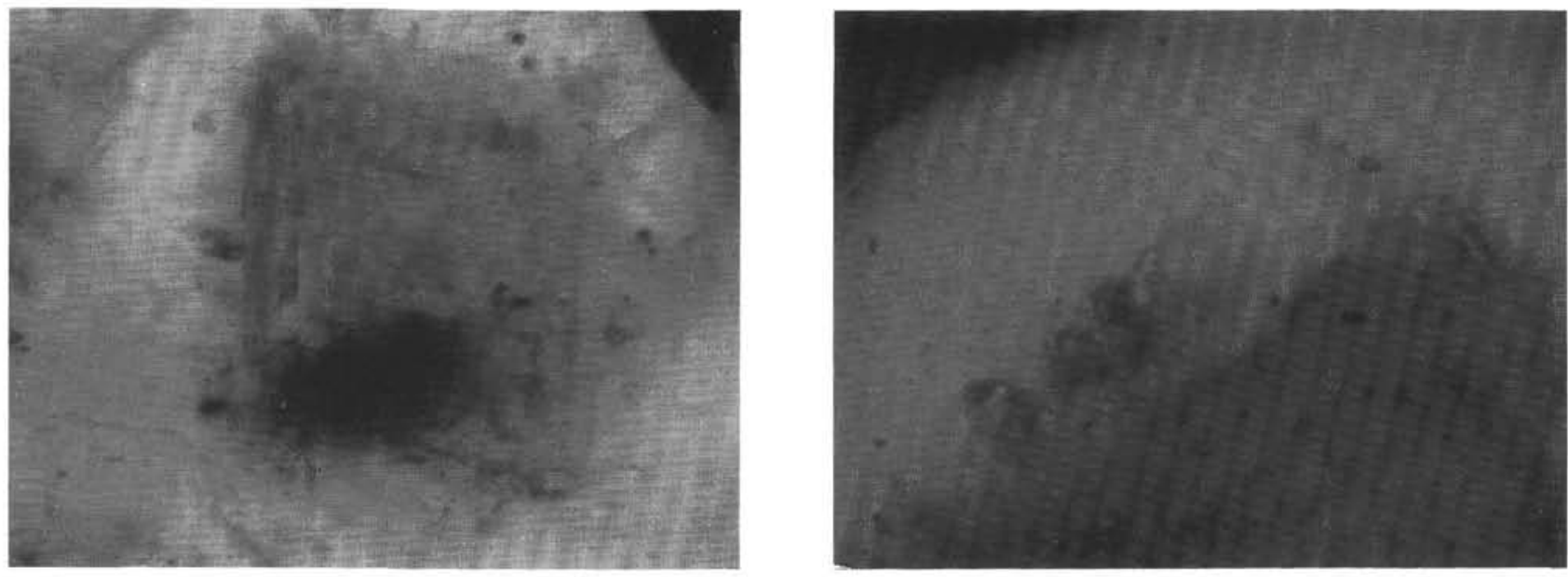

C
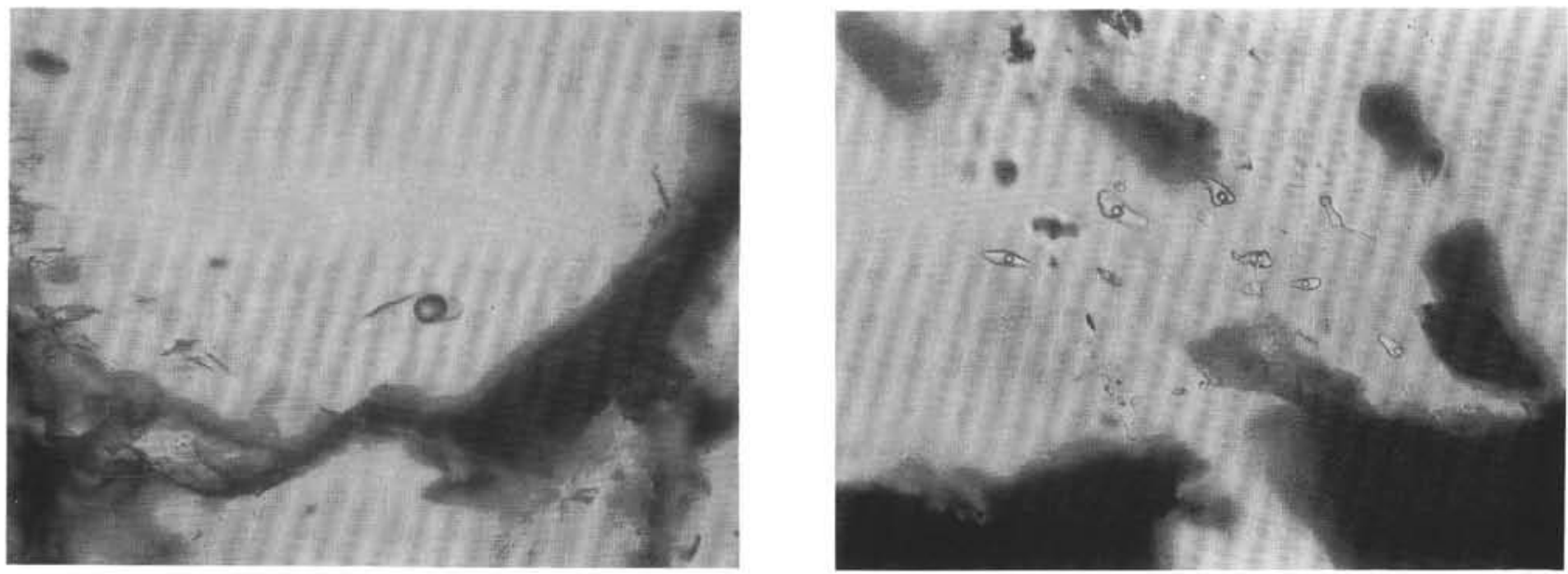

E

Plate 3. Transmitted light photomicrographs of fluid inclusions. A. Rectangular primary two-phase (L,V) 40- $\mu \mathrm{m}$ inclusion in anhydrite, Sample 858A-29X-1, $30-32 \mathrm{~cm}$. B. Needle-like primary two-phase (L,V) 70- and 50- $\mu \mathrm{m}$-long inclusions oriented parallel to cleavage in anhydrite, Sample 857D-1R-1, 137-139 cm. C. Growth zones in carbonate defined by primary two-phase (L,V) 2- to 7- $\mu$ m inclusions and solid inclusions, Sample $856 \mathrm{H}-3 \mathrm{R}-1,28-30 \mathrm{~cm}$. D. Close-up of growth zone in carbonate showing irregular 7- $\mu \mathrm{m}$ two-phase (L,V) primary inclusion, Sample 856H-3R-2, 135-138 cm. E. Primary two-phase (L,V) $70-\mu \mathrm{m}$ inclusion in wairakite from quartz-wairakite-epidote vein in mafic sill, Sample 857D-12R-1, 88-90 cm. F. Cluster of 10- to 15- $\mu$ m-diameter secondary two-phase (L,V) inclusions along a fracture in the plane of the fluid inclusion section in quartz from quartz-wairakite vein cutting a mafic sill, Sample $857 \mathrm{C}-60 \mathrm{R}-2,28^{\circ} 30 \mathrm{~cm}$. 